\title{
Performance Evaluation of Micronized-Magnetite Cycloning as a Function of Key Operational Variables
}

\section{Office of Science \& Technology Research Report}

Carl P. Maronde ${ }^{1}$, Richard P. Killmeyer ${ }^{1}$, Michael V. Ciocco ${ }^{2}$, and Paul H. Zandhuis ${ }^{2}$

\author{
${ }^{1}$ U.S. Department of Energy \\ National Energy Technology Laboratory \\ ${ }^{2}$ Parsons Project Services, Inc. \\ 626 Cochrans Mill Road, P.O. Box 10940 \\ Pittsburgh, PA 15236-0940 \\ and \\ 3610 Collins Ferry Road, P.O. Box 880 \\ Morgantown, WV 26507-0880
}

December 30, 1999
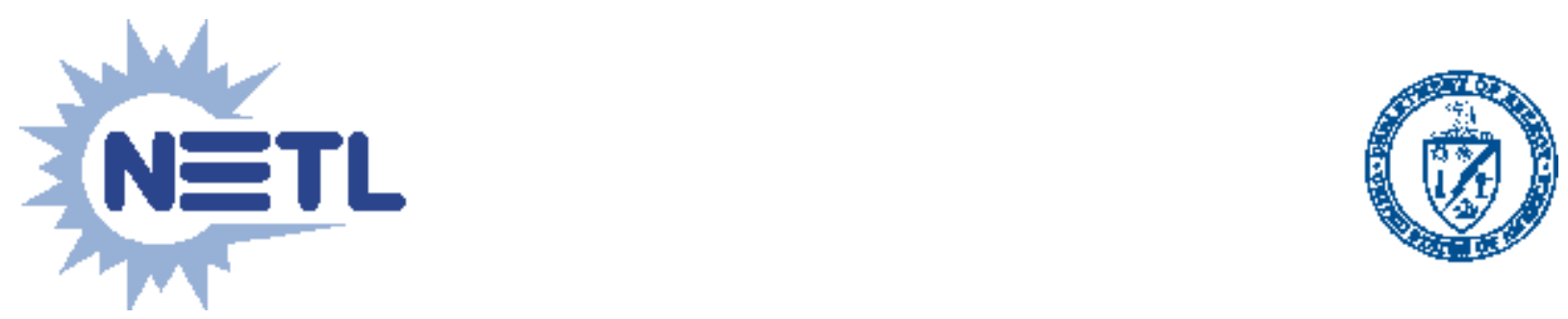


\title{
Disclaimer
}

This report was prepared as an account of work sponsored by an agency of the United States Government. Neither the United States Government nor any agency thereof, nor any of their employees, makes any warranty, express or implied, or assumes any legal liability or responsibility for the accuracy, completeness, or usefulness of any information, apparatus, product, or process disclosed, or represents that its use would not infringe privately owned rights. Reference therein to any specific commercial product, process, or service by trade name, trademark, manufacturer, or otherwise does not necessarily constitute or imply its endorsement, recommendation, or favoring by the United States Government or any agency thereof. The views and opinions of authors expressed therein do not necessarily state or reflect those of the United States Government or any agency thereof.

\begin{abstract}
In 1997, Custom Coals International completed a DOE contract to test the Micro-Mag Process at the continuous bench-scale at DOE's National Energy Technology Laboratory (NETL). As a follow up to these tests, NETL conducted two series of tests to confirm the Custom Coals results and to expand upon the effects of key operational variables on cyclone performance when using magnetite that is finer than conventional Grade E magnetite. This report details the results of batch tests in which the variables were magnetite size, medium density, cyclone orifice sizes, and inlet pressure. The results show that fairly sharp separations (about 0.060-0.090 Ep) can be achieved on coal as fine as 48 x 500 mesh if magnetite that is only about twice as fine as Grade $\mathrm{E}$ is used at higher inlet pressures (greater than 20 psi) with the right combination of cyclone orifice sizes.
\end{abstract}




\section{Contents}

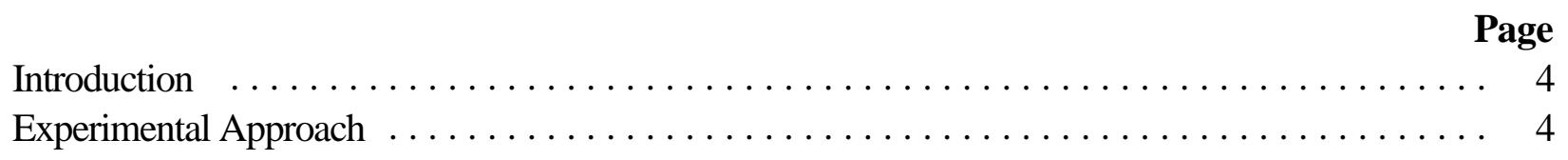

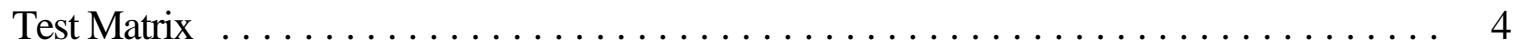

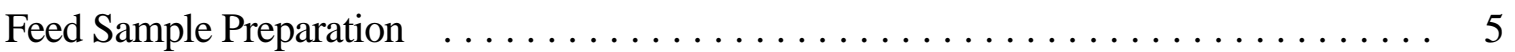

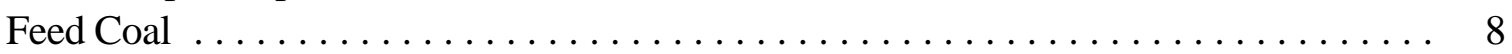

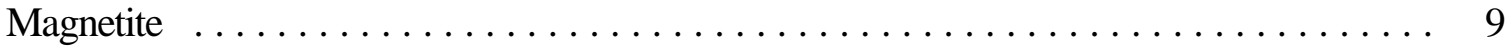

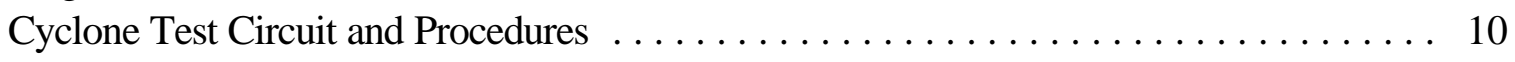

Performance Evaluation Methodology $\ldots \ldots \ldots \ldots \ldots \ldots \ldots \ldots \ldots \ldots \ldots \ldots \ldots$

Test Results $\ldots \ldots \ldots \ldots \ldots \ldots \ldots \ldots \ldots \ldots \ldots \ldots \ldots \ldots \ldots \ldots \ldots \ldots$

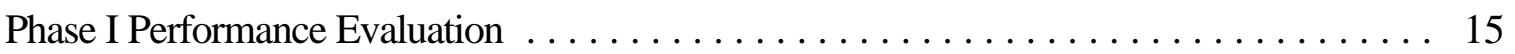

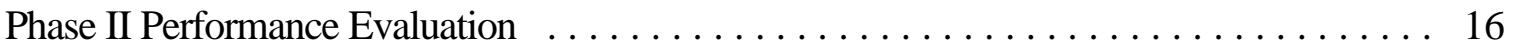

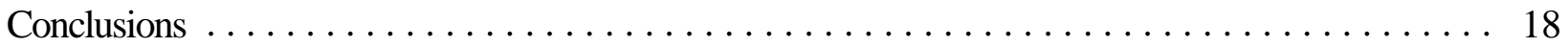

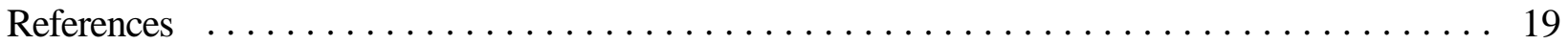

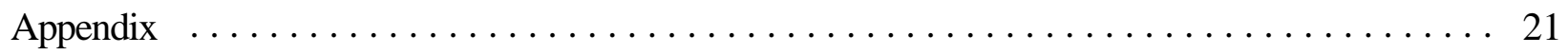

\section{Figures and Tables}

Figure Page

1 Flow Diagram of Classification Circuit for Feed Coal Preparation . . . . . . . . . . . . 7

2 Flow Diagram for the Closed-Loop Dense-Medium Cyclone Circuit $\ldots \ldots \ldots \ldots \ldots$

Table Page

1 Micronized-Magnetite Cycloning Phase I Test Matrix $\ldots \ldots \ldots \ldots \ldots \ldots \ldots \ldots$

2 Micronized-Magnetite Cycloning Phase II Test Matrix $\ldots \ldots \ldots \ldots \ldots \ldots \ldots \ldots$

3 Characterization of Phase I Sample Preparation Product $\ldots \ldots \ldots \ldots \ldots \ldots \ldots \ldots$

4 Size Distribution of Phase I Sample Preparation Product $\ldots \ldots \ldots \ldots \ldots \ldots \ldots$

5 Cyclone Feed Coal Characteristics $\ldots \ldots \ldots \ldots \ldots \ldots \ldots \ldots \ldots \ldots \ldots$

6 Size Distributions of the Test Magnetites Compared to Commercial Grades B \& E . . . . 10

7 Guide to Analyzing the Test Results From Phase I — Test Numbers and SEIs . . . . . . 13

8 Guide to Analyzing the Test Results From Phase II — Test Numbers and SEIs . . . . . 14 


\section{Introduction}

In the early 1990's, DOE developed a fine-coal cleaning process called the Micro-Mag Process (1), which entails the use of micronized magnetite in formulating a dense-medium for cleaning fine coal in a cyclone. This process differs from conventional dense-medium cyclone operations in that the micronized magnetite is much finer in size consist. For example, the finest grade of conventional magnetite from one commercial supplier was nearly $100 \%<45$ microns, with about $15 \%<5$ microns, while micronized magnetite is on the order of $100 \%<10$ microns, with over $50 \%<5$ microns.

At about the same time, Custom Coals International developed similar technology and in 1993 exclusively licensed DOE's Micro-Mag Process as part of their effort to commercialize the technology through DOE's Clean Coal Technology Program. Results of several R\&D studies of various aspects of the micronized-magnetite cycloning technology conducted by NETL's in-house researchers have been extensively documented (2-10). These studies were generally conducted under closed-loop, batch conditions. In 1995-97, as part of a DOE High Efficiency Preparation solicitation, Custom Coals International completed a cost-shared contract with DOE to evaluate and advance the micronizedmagnetite cycloning technology through the design, construction, and operation of a fully integrated, 500 lb/hr, continuous circuit at NETL's Solids Processing Research Facility (SPRF) in Pittsburgh, PA (11, 12).

While the Custom Coals project demonstrated the feasibility of the technology at the continuous benchscale with regard to feed classification, dense-medium cyclone separation, and magnetite recovery, it also recommended that additional dense-medium cyclone testing be conducted to verify some of the findings obtained in the long-term tests, fill in some data gaps still remaining, and examine the effects of key operational variables on performance, particularly magnetite size consist. This report summarizes the results of such a follow-up study, conducted by NETL, using a closed-loop, batch-mode circuit in NETL's Solids Processing Research Facility.

\section{Experimental Approach}

\section{Test Matrix}

A total of 40 tests were run, as shown in Tables 1 and 2, of which 30 were submitted for float-sink analysis in order to construct partition curves. The tests were conducted in two phases. Phase I covered Tests 1-1 through 1-17 and focused on magnetite grade, medium density, and apex orifice size. Phase II was designed as a follow up to Phase I and covered Tests 2-1 through 2-23, focusing on cyclone inlet pressure and cyclone geometry.

In Phase I, Tests 5, 8, and 10 were identical tests run on different days as a quality assurance (QA/QC) measure in order to determine the precision that could be expected for a set of cyclone performance data. This is necessary in order to allow for interpretation of the data obtained by varying certain test conditions. For test 8 , three sets of samples were collected from the product streams in a 
sequential fashion resulting in tests designated as $8 \mathrm{~A}, 8 \mathrm{~B}$, and $8 \mathrm{C}$. This was done in order to determine the degree of precision that could be expected as a result of the processing, handling, splitting, and analyzing of the samples.

Table 1. Micronized-Magnetite Cycloning Phase I Test Matrix

\begin{tabular}{|c|c|c|c|c|c|c|c|}
\hline \multirow[b]{2}{*}{ TEST NO. } & \multicolumn{7}{|c|}{ OPERATING CONDITIONS } \\
\hline & $\begin{array}{c}\text { MAG } \\
\text { GRADE }\end{array}$ & $\begin{array}{c}\text { FEED } \\
\text { PRESSURE } \\
\text { (PSI) }\end{array}$ & $\begin{array}{c}\text { MEDIUM } \\
\text { DENSITY } \\
(\mathrm{G} / \mathrm{CC}) \\
\end{array}$ & $\begin{array}{c}\text { APEX } \\
\text { ORIFICE } \\
\text { (INCHES) }\end{array}$ & $\begin{array}{l}\text { INLET } \\
\text { ORIFICE } \\
\text { (SQ IN) }\end{array}$ & $\begin{array}{c}\text { PARTITION } \\
\text { DATA } \\
\text { 48X200M }\end{array}$ & $\begin{array}{l}\text { PARTITION } \\
\text { DATA } \\
\text { 200X500M }\end{array}$ \\
\hline $1-1$ & $\mathrm{~K}$ & 90 & 1.30 & 0.625 & 0.120 & & $\mathrm{X}$ \\
\hline $1-2$ & $\mathrm{~K}$ & 90 & 1.40 & 0.625 & 0.120 & $\mathrm{X}$ & $\mathrm{X}$ \\
\hline $1-3$ & $\mathrm{~K}$ & 90 & 1.40 & 0.875 & 0.120 & & X \\
\hline $1-4$ & $\mathrm{~L}$ & 90 & 1.30 & 0.625 & 0.120 & & X \\
\hline $1-5$ & $\mathrm{~L}$ & 90 & 1.40 & 0.625 & 0.120 & $\mathrm{X}$ & $\mathrm{X}$ \\
\hline $1-6$ & $\mathrm{~L}$ & 90 & 1.40 & 1.000 & 0.120 & & $\mathrm{X}$ \\
\hline $1-7$ & $\mathrm{~L}$ & 90 & 1.40 & 0.875 & 0.120 & & $\mathrm{X}$ \\
\hline $1-8 \mathrm{~A}$ & $\mathrm{~L}$ & 90 & 1.40 & 0.625 & 0.120 & & $X$ \\
\hline $1-8 \mathrm{~B}$ & $\mathrm{~L}$ & 90 & 1.40 & 0.625 & 0.120 & & $\mathrm{X}$ \\
\hline $1-8 \mathrm{C}$ & $\mathrm{L}$ & 90 & 1.40 & 0.625 & 0.120 & $\mathrm{X}$ & $X$ \\
\hline $1-9$ & $\mathrm{~L}$ & 20 & 1.40 & 0.625 & 0.375 & $\mathrm{X}$ & $\mathrm{X}$ \\
\hline $1-10$ & $\mathrm{~L}$ & 90 & 1.40 & 0.625 & 0.120 & & $X$ \\
\hline $1-11$ & M & 90 & 1.20 & 0.625 & 0.120 & & $X$ \\
\hline $1-12$ & M & 90 & 1.30 & 0.625 & 0.120 & & $X$ \\
\hline $1-13$ & $\mathrm{M}$ & 90 & 1.40 & 0.625 & 0.120 & $X$ & $X$ \\
\hline $1-14$ & M & 90 & 1.40 & 0.875 & 0.120 & & $X$ \\
\hline $1-15$ & $60 X$ & 90 & 1.30 & 0.625 & 0.120 & & $X$ \\
\hline $1-16$ & $60 X$ & 90 & 1.40 & 0.625 & 0.120 & $\mathrm{X}$ & $X$ \\
\hline $1-17$ & $60 X$ & 90 & 1.40 & 0.875 & 0.120 & & $X$ \\
\hline
\end{tabular}

In Phase II, replicate tests (Tests 2, 19, 21, and 23) were run to again measure the degree of precision.

\section{Feed Sample Preparation}

The goal of the feed sample preparation operation was to produce equivalent $48 \times 500$ mesh coal samples to be used as feed for the dense-medium cyclone tests. The feed samples for Phase I and for Phase II were prepared at different times using different portions of the same lot of raw coal. 
Table 2. Micronized-Magnetite Cycloning Phase II Test Matrix

\begin{tabular}{|c|c|c|c|c|c|c|c|}
\hline \multirow[b]{2}{*}{ TEST NO. } & \multicolumn{7}{|c|}{ OPERATING CONDITIONS } \\
\hline & $\begin{array}{c}\text { MAG } \\
\text { GRADE }\end{array}$ & $\begin{array}{c}\text { FEED } \\
\text { PRESSURE } \\
\text { (PSI) }\end{array}$ & $\begin{array}{c}\text { MEDIUM } \\
\text { DENSITY } \\
(\mathrm{G} / \mathrm{CC})\end{array}$ & $\begin{array}{c}\text { APEX } \\
\text { ORIFICE } \\
\text { (INCHES) }\end{array}$ & $\begin{array}{l}\text { INLET } \\
\text { ORIFICE } \\
\text { (SQ IN) }\end{array}$ & $\begin{array}{l}\text { PARTITION } \\
\text { DATA } \\
\text { 48X200M }\end{array}$ & $\begin{array}{l}\text { PARTITION } \\
\text { DATA } \\
\text { 200X500M }\end{array}$ \\
\hline $2-1$ & $60 X$ & 20 & 1.20 & 0.625 & 0.120 & & \\
\hline $2-2$ & $60 x$ & 50 & 1.20 & 0.625 & 0.120 & $\mathrm{X}$ & $\mathrm{X}$ \\
\hline $2-3$ & $60 X$ & 90 & 1.20 & 0.625 & 0.120 & & \\
\hline $2-4$ & $60 X$ & 20 & 1.20 & 0.875 & 0.120 & & \\
\hline $2-5$ & $60 X$ & 50 & 1.20 & 0.875 & 0.120 & & \\
\hline $2-6$ & $60 \mathrm{X}$ & 90 & 1.20 & 0.875 & 0.120 & & \\
\hline $2-7$ & $60 X$ & 20 & 1.20 & 0.875 & 0.375 & & \\
\hline $2-8$ & $60 \mathrm{X}$ & 50 & 1.20 & 0.875 & 0.375 & & $\mathrm{X}$ \\
\hline $2-9$ & $60 X$ & 90 & 1.20 & 0.875 & 0.375 & & \\
\hline $2-10$ & $60 X$ & 20 & 1.20 & 0.625 & 0.375 & $\mathrm{X}$ & $\mathrm{X}$ \\
\hline $2-11$ & $60 X$ & 50 & 1.20 & 0.625 & 0.375 & $X$ & X \\
\hline $2-12$ & $60 X$ & 90 & 1.20 & 0.625 & 0.375 & $X$ & $X$ \\
\hline $2-13$ & $60 X$ & 20 & 1.30 & 0.625 & 0.375 & $X$ & $X$ \\
\hline $2-14$ & $60 X$ & 50 & 1.30 & 0.625 & 0.375 & $X$ & $X$ \\
\hline $2-15$ & $60 X$ & 80 & 1.30 & 0.625 & 0.375 & $X$ & $X$ \\
\hline $2-16$ & $60 X$ & 20 & 1.30 & 0.625 & 0.120 & & \\
\hline 2-17 & $60 X$ & 50 & 1.30 & 0.625 & 0.120 & $X$ & $X$ \\
\hline $2-18$ & $60 X$ & 80 & 1.30 & 0.625 & 0.120 & $X$ & $X$ \\
\hline 2-19 & $60 X$ & 50 & 1.20 & 0.625 & 0.120 & $X$ & $X$ \\
\hline $2-20$ & $60 X$ & 20 & 1.20 & 0.625 & 0.120 & & \\
\hline $2-21$ & $60 X$ & 50 & 1.20 & 0.625 & 0.120 & $X$ & $X$ \\
\hline $2-22$ & $60 X$ & 80 & 1.20 & 0.625 & 0.120 & & \\
\hline $2-23$ & $60 X$ & 50 & 1.20 & 0.625 & 0.120 & $\mathrm{X}$ & $\mathrm{X}$ \\
\hline
\end{tabular}

Figure 1 shows the block flow diagram of the size classification circuit utilized for feed sample preparation. The feed slurry to the classification circuit was generated by first grinding air-dried raw coal to a 48-mesh top size using a hammermill in the SPRF, followed by the addition of water to constitute a $30 \%$ solids slurry. This slurry was then pumped to the classification circuit. The feed slurry was delivered to the north side of a double-sided fine-coal deslime screen containing a 325-mesh 
screen with sprays. The north screen oversize reported to the classifying cyclone sump, and the undersize reported to the waste sump. The overflow was then pumped to the two-inch diameter classifying cyclone. The classifying cyclone overflow (500 mesh x 0) was sent to the waste sump while the classifying cyclone underflow was sent to the south side of the fine-coal deslime screen containing a 100-mesh screen without sprays. This screening step essentially was used to increase and control the solids concentration of the final product slurry. Any potential product in the south screen underflow reported back to the classifying cyclone sump, while the screen overflow (48 mesh x 500 mesh) was collected as feed for the dense-medium cyclone tests.

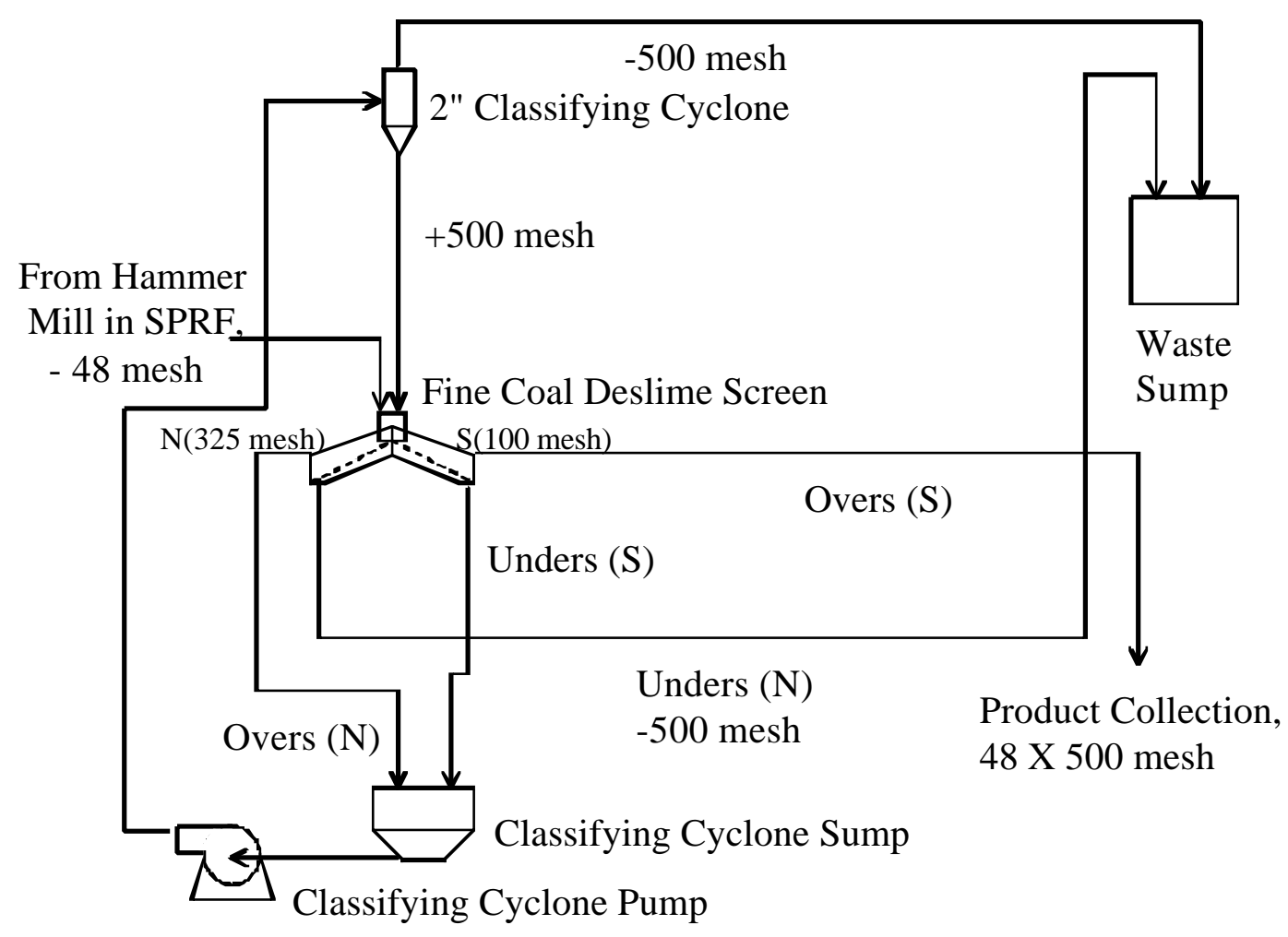

Figure 1. Flow Diagram of Classification Circuit for Feed Coal Preparation

The first $100 \mathrm{lbs}$ of the final fine-coal deslime screen overflow ( 48 x 500 mesh) was discarded. The rest of the product was split into 12 drums by sequentially placing 3-gallon incremental samples of slurry into each of the drums. At the end of each incremental cycle of placing one sample in each of the 12 drums, two 5-gallon and one 1-gallon samples were taken and stored individually. In total, for Phase I testing, 12 drums ( 55 lbs coal), 16 buckets (6-7 lbs coal), and 8 cans (4-5 lbs) were produced. The amount of collected sample was increased for the Phase II feed preparation. Also, the variation in the amount of individual sample was increased for the Phase II samples in order to improve the slurry preparation flexibility with respect to Phase I. For Phase II testing, 20 drums ( 90 lbs coal), 6 drums ( $45 \mathrm{lbs}$ coal), 24 buckets (4-15 lbs coal), and 8 cans (2-3 lbs) were produced. 
A number of the buckets: 1, 2 (duplicates $a \& b$ ), 3, 5 (duplicates a\&b), 6, 8 (duplicates a\&b), and one of the drums: 1 (duplicates $\mathrm{a} \& \mathrm{~b}$ ) from the Phase I sample preparation tests were analyzed in order to confirm sample equivalence. The size distribution, ash content, sulfur content, calorific value, and pyritic sulfur content of these samples were analyzed. The results are summarized in Tables 3 and 4 and the results confirm that equivalent samples were produced. Samples were also analyzed from the feed preparation samples of Phase II again confirming the equivalence of sample splits.

Table 3. Characterization of Phase I Sample Preparation Product (48 x 500 Mesh Raw Coal)

\begin{tabular}{|l|c|c|c|c|}
\hline Feed & \%Ash & \% Sulfur & Btu/lb & \% P. Sul. \\
\hline Drum 1a & 17.64 & 4.23 & 14418 & 2.30 \\
\hline Drum 1b & 17.63 & 4.15 & 14467 & 2.31 \\
\hline Bucket 2a & 15.27 & 4.02 & 14625 & 1.84 \\
\hline Bucket 2b & 15.22 & 3.88 & 14582 & 1.85 \\
\hline Bucket 3 & 17.13 & 4.23 & 14251 & 2.04 \\
\hline Bucket 5a & 17.26 & 4.23 & 14633 & 2.19 \\
\hline Bucket 5b & 17.41 & 4.10 & 14504 & 1.94 \\
\hline Bucket 8a & 16.87 & 4.32 & 14598 & 2.28 \\
\hline Bucket 8b & 16.32 & 4.01 & 14474 & 2.21 \\
\hline Average & 16.75 & 4.13 & 14506 & 2.11 \\
\hline STD & 0.94 & 0.14 & 122.4 & 0.19 \\
\hline
\end{tabular}

Table 4. Size Distribution of Phase I Sample Preparation Product (48 x 500 Mesh Raw Coal)

\begin{tabular}{|c|c|c|c|c|c|c|}
\hline & \multicolumn{7}{|c|}{ Size Fraction Weight \% } \\
\hline Feed & $\mathbf{+ 4 8 m}$ & $\mathbf{4 8 m X ~ 1 0 0 m}$ & $\begin{array}{c}\mathbf{1 0 0} \mathbf{m X} \\
\mathbf{2 0 0 m}\end{array}$ & $\begin{array}{c}\mathbf{2 0 0} \mathbf{m X} \\
\mathbf{3 2 5} \mathbf{m}\end{array}$ & $\begin{array}{c}\mathbf{3 2 5} \mathbf{m X} \\
\mathbf{5 0 0 m}\end{array}$ & $\mathbf{- 5 0 0 m}$ \\
\hline Drum-1a & 6.37 & 25.48 & 33.87 & 17.18 & 9.68 & 7.42 \\
\hline Drum-1b & 6.06 & 25.39 & 34.36 & 17.10 & 9.38 & 7.71 \\
\hline Bucket 1 & 4.50 & 21.67 & 36.39 & 18.45 & 12.70 & 6.29 \\
\hline Bucket 2a & 7.10 & 30.43 & 37.85 & 13.14 & 6.96 & 4.52 \\
\hline Bucket 2b & 7.01 & 30.46 & 35.97 & 15.70 & 6.60 & 4.26 \\
\hline Bucket 3 & 6.80 & 24.84 & 32.85 & 18.62 & 9.61 & 7.28 \\
\hline Bucket 5a & 8.14 & 25.69 & 35.35 & 15.72 & 8.82 & 6.28 \\
\hline Bucket 5b & 7.43 & 24.70 & 36.13 & 16.72 & 8.98 & 6.04 \\
\hline Bucket 6 & 7.47 & 24.84 & 32.04 & 18.81 & 9.25 & 7.59 \\
\hline Bucket 8a & 6.86 & 27.00 & 34.15 & 18.04 & 8.46 & 5.49 \\
\hline Bucket 8b & 5.75 & 24.42 & 37.12 & 19.19 & 8.10 & 5.42 \\
\hline Average & 6.68 & 25.90 & 35.10 & 17.15 & 8.96 & 6.21 \\
\hline STD & 0.94 & 2.46 & 1.72 & 1.70 & 1.53 & 1.15 \\
\hline
\end{tabular}

\section{Feed Coal}

The coal used for this study was from the Pittsburgh \#8 Seam located in Belmont Co., Ohio. The coal was prepared as described in the previous section to obtain a 48 x 500 mesh size fraction to use as 
feed to the dense-medium cyclones. Analysis of a head sample showed the coal to have the size and washability characteristics presented in Table 5.

Table 5. Cyclone Feed Coal Characteristics

\begin{tabular}{|c|c|c|c|c|c|c|c|c|}
\hline \multicolumn{9}{|c|}{ Size Distribution } \\
\hline Mesh & Weight & $\begin{array}{c}\text { Cum. } \\
\text { Wt. }\end{array}$ & Ash & Total S. & Pyr. S. & $\begin{array}{c}\text { Cum. } \\
\text { Ash }\end{array}$ & $\begin{array}{c}\text { Cum. } \\
\text { Total S. }\end{array}$ & $\begin{array}{l}\text { Cum. } \\
\text { Pyr. S. }\end{array}$ \\
\hline Plus 48 & 6.37 & 6.37 & 19.60 & 3.64 & 1.67 & 19.60 & 3.64 & 1.67 \\
\hline $48 \times 100$ & 25.48 & 31.85 & 16.06 & 3.82 & 1.98 & 16.77 & 3.78 & 1.92 \\
\hline $100 \times 200$ & 33.87 & 65.72 & 13.56 & 3.88 & 1.99 & 15.11 & 3.83 & 1.96 \\
\hline $200 \times 325$ & 17.18 & 82.90 & 13.42 & 3.88 & 2.18 & 14.76 & 3.84 & 2.00 \\
\hline $325 \times 500$ & 9.68 & 92.58 & 15.39 & 4.34 & 2.67 & 14.83 & 3.90 & 2.07 \\
\hline Minus 500 & 7.42 & 100 & 52.28 & 5.15 & 4.44 & 17.61 & 3.99 & 2.25 \\
\hline \multicolumn{9}{|c|}{$48 \times 200$ Mesh Float-sink } \\
\hline Sp. Gravity & Weight & $\begin{array}{c}\text { Cum. } \\
\text { Wt. }\end{array}$ & Ash & Total S. & Pyr. S. & $\begin{array}{c}\text { Cum. } \\
\text { Ash }\end{array}$ & $\begin{array}{c}\text { Cum. } \\
\text { Total S. }\end{array}$ & $\begin{array}{l}\text { Cum. } \\
\text { Pyr. S. }\end{array}$ \\
\hline $\mathrm{Fl}-1.30$ & 44.4 & 44.4 & 2.62 & 2.45 & 0.13 & 2.62 & 2.45 & 0.13 \\
\hline $1.30-1.40$ & 32.81 & 77.21 & 7.63 & 3.16 & 1.01 & 4.75 & 2.75 & 0.50 \\
\hline $1.40-1.60$ & 9.87 & 87.08 & 20.51 & 4.96 & 3.22 & 6.54 & 3.00 & 0.81 \\
\hline $1.60-1.90$ & 3.17 & 90.25 & 38.23 & 6.36 & 4.65 & 7.65 & 3.12 & 0.95 \\
\hline $1.90-2.40$ & 1.76 & 92.01 & 58.44 & 7.64 & 6.69 & 8.62 & 3.21 & 1.06 \\
\hline Sk -2.40 & 7.99 & 100 & 81.86 & 10.55 & 10.19 & 14.47 & 3.79 & 1.79 \\
\hline \multicolumn{9}{|c|}{$200 \times 500$ Mesh Float-sink } \\
\hline Sp. Gravity & Weight & $\begin{array}{c}\text { Cum. } \\
\text { Wt. }\end{array}$ & Ash & Total S. & Pyr. S. & $\begin{array}{c}\text { Cum. } \\
\text { Ash }\end{array}$ & $\begin{array}{c}\text { Cum. } \\
\text { Total S. }\end{array}$ & $\begin{array}{l}\text { Cum. } \\
\text { Pyr. S. }\end{array}$ \\
\hline $\mathrm{Fl}-1.30$ & 44.46 & 44.46 & 2.09 & 2.28 & 0.05 & 2.09 & 2.28 & 0.05 \\
\hline $1.30-1.40$ & 30.56 & 75.02 & 5.73 & 2.57 & 0.47 & 3.57 & 2.40 & 0.22 \\
\hline $1.40-1.60$ & 8.26 & 83.28 & 16.19 & 3.69 & 2.56 & 4.82 & 2.53 & 0.45 \\
\hline $1.60-1.90$ & 2.99 & 86.27 & 31.42 & 6.05 & 4.66 & 5.75 & 2.65 & 0.60 \\
\hline $1.90-2.40$ & 2.27 & 88.54 & 53.62 & 9.84 & 6.58 & 6.97 & 2.83 & 0.75 \\
\hline $\mathrm{Sk}-2.40$ & 11.46 & 100 & 79.75 & 15.77 & 15.11 & 15.31 & 4.32 & 2.40 \\
\hline
\end{tabular}

\section{Magnetite}

Four grades of finely ground magnetite were used for the test program, as described below:

C PennMag Grade K -- mean particle size of $10.1 \mathrm{Fm}$

C PennMag Grade L -- mean particle size of $7.2 \mathrm{Fm}$

C Pea Ridge Grade M -- mean particle size of $2.8 \mathrm{Fm}$

C Pea Ridge Grade 60x -- mean particle size of 4.8Fm

Grades K, L, and M were the same magnetites that were used by Custom Coals during their DOE project that was described earlier. Grade $60 \mathrm{X}$ was specially obtained for this project to provide a grade of magnetite with a size consist between that of grades $\mathrm{L}$ and $\mathrm{M}$. The particle size distributions 
for all four grades, as determined by Microtrac $®$ analysis, are shown in Table 6, along with typical size consists for grade B and E magnetites that are used widely throughout the coal industry.

Table 6. Size Distributions of the Test Magnetites Compared to Commercial Grades B \& E

\begin{tabular}{|c|c|c|c|c|c|c||}
\hline $\begin{array}{c}\text { Microtrac } \\
\text { Size, Fm }\end{array}$ & $\begin{array}{c}\text { Grade B, } \\
\text { \% passing }\end{array}$ & $\begin{array}{c}\text { Grade E, } \\
\text { \% passing }\end{array}$ & $\begin{array}{c}\text { Grade K, } \\
\text { \% passing }\end{array}$ & $\begin{array}{c}\text { Grade L, } \\
\text { \% passing }\end{array}$ & $\begin{array}{c}\text { Grade } \\
\text { 60X, } \\
\text { passing }\end{array}$ & $\begin{array}{c}\text { Grade M, } \\
\text { \% passing }\end{array}$ \\
\hline 44.0 & 100.0 & 100.0 & 100.0 & 100.0 & 100.0 & 100.0 \\
\hline 31.0 & 84.5 & 98.1 & 100.0 & 100.0 & 100.0 & 100.0 \\
\hline 22.0 & 69.5 & 91.2 & 98.1 & 100.0 & 100.0 & 100.0 \\
\hline 16.0 & 57.0 & 73.4 & 86.2 & 95.4 & 98.1 & 100.0 \\
\hline 11.0 & 39.5 & 54.1 & 63.6 & 82.7 & 93.1 & 100.0 \\
\hline 7.8 & 28.5 & 26.5 & 38.6 & 63.9 & 85.2 & 100.0 \\
\hline 5.5 & 16.1 & 13.3 & 19.8 & 43.7 & 72.6 & 95.7 \\
\hline 3.9 & 9.5 & 5.6 & 8.3 & 25.4 & 56.6 & 86.1 \\
\hline 2.8 & 4.0 & 3.0 & 2.6 & 11.3 & 33.9 & 55.6 \\
\hline 1.9 & 0.0 & 1.0 & 0.2 & 3.1 & 13.9 & 23.7 \\
\hline 1.4 & 0.0 & 0.0 & 0.0 & 1.0 & 6.3 & 11.1 \\
\hline 0.9 & 0.0 & 0.0 & 0.0 & 0.0 & 1.6 & 3.1 \\
\hline D50 & 13.50 & 10.80 & 9.25 & 6.22 & 3.58 & 2.64 \\
\hline \hline
\end{tabular}

\section{Cyclone Test Circuit and Procedures}

Figure 2 shows the block flow diagram of the closed-loop, batch-mode circuit for dense-medium cyclone testing. A slurry of measured amounts of $48 \times 500$ mesh coal, magnetite, and water was prepared in an 80-gallon dense-medium cyclone feed sump to meet the desired conditions for several tests. This slurry was pumped to a Krebs 4" dense-medium cyclone. The overflow and underflow from the cyclone were directed to a sampling box where underflow and overflow samples were collected. The underflow and overflow streams would then combine and flow back to the fine dense-medium cyclone feed sump.

Sampling was done via the simultaneous collection of timed, full-stream cuts of both the cyclone overflow and underflow product streams. The following data were collected for both the composite overflow and composite underflow samples and for their size fractions of $48 \times 200$ mesh and $200 \times$ 500 mesh: slurry flow rates, solids flow rates, and ash content. In addition, for Phase I only, total sulfur and pyritic sulfur were obtained in order to gain insight into pyrite reduction efficiency. For select samples, float-sink analyses were conducted at specific gravities of 1.30, 1.40, 1.60, 1.90, and 2.40. Due the expense of conducting float-sink analysis on such fine size coal, the number of tests for which distribution curve analysis was conducted was limited. Selection of the tests for this analysis was based on calculated Btu recovery/ash reduction and to highlight the effects of specific operating conditions. 


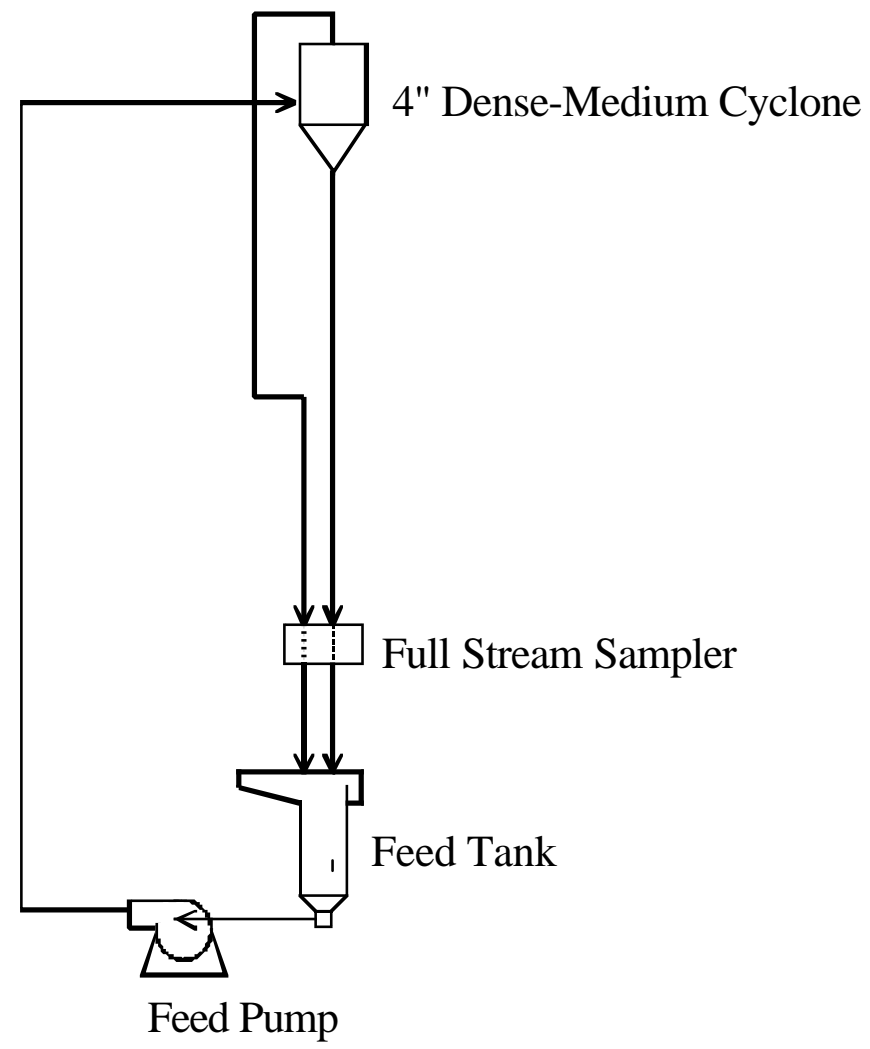

Figure 2. Flow Diagram for the Closed-Loop Dense-Medium Cyclone Circuit

\section{Performance Evaluation Methodology}

There are many different parameters one can look at in trying to draw conclusions about the effects of certain variables on cyclone performance, depending on one's interests and the relevance and credibility of the test data. For this study it was decided to evaluate the data using two performance measures -- the Separation Efficiency Index (SEI) and Probable Error (Ep) value. Each of these measures was determined for each of the two size fractions used in this study -- 48 × 200 mesh and $200 \times 500$ mesh. It must be emphasized that SEI values are coal and SG50 specific, whereas Ep values are equipment specific, but for the various reasons explained below, both had their advantages for application in this study.

The SEI is based on the quantity and quality of the feed and products and is defined as: (Yield \% $\mathrm{x}$ Refuse Ash \%) / Clean Coal Ash \%. It is essentially a measure of the sharpness of separation based on the grade and recovery of the products in relation to the feed, and it varies with location on the washability curve, generally being the highest at the elbow of the curve. The SEI was calculated for each test run in the study.

The Ep value is one of many separation performance indicators that can be determined from partition curves. The partition curves and the curve-derived performance parameters, including $\mathrm{E}_{\mathrm{P}}$ and the 
specific gravity of separation, presented in this report were generated using laboratory float-sink data and a Weibull-based, curve-fitting mathematical function applied through the Solver routine as found in the Microsoft Excel spreadsheet software. Hand-drawn curves were not used as, very early on in the testing, it was found that different project personnel produced significantly different probable error values from the same distribution data. In a brief study related to this project (13), Science Applications International Corporation and NETL researchers found that the curve-fitting mathematical function technique provided for a fairly accurate and, more importantly, unbiased and consistent methodology for generating the distribution curves and the curve-derived performance parameters.

Commercial Testing and Engineering in Henderson, KY was contracted to perform the fine-size centrifugal float-sink testing on the 4" cyclone clean-coal and refuse products. This laboratory was selected to perform this analytical work because it was very experienced in centrifugal float-sink testing and was using the latest available techniques as developed by Process Technology, Inc. through a DOE/NETL contract (14). The raw float-sink data along with product yields and size distribution data were used to produce partition data. This data was then used to generate the partition curves and probable error and specific gravity of separation values by using the Weibull curve-fitting function according to the following equation:

$$
\mathrm{K}=(1-\mathrm{a}-\mathrm{b})\left(1 /\left(1+\mathrm{z}^{\mathrm{c}}\right)\right)+\mathrm{a}
$$

where $\mathrm{K}$ is the partition factor, $\mathrm{a}$ and $\mathrm{b}$ are bypass factors representing material that bypasses directly to the overflow or underflow, $\mathrm{c}$ is a function parameter, and $\mathrm{z}=\mathrm{x} / \mathrm{SG}_{50}$, where $\mathrm{x}$ is the relative density and $\mathrm{SG}_{50}$ is the specific gravity of separation.

In this report, the approach taken was to use the coal-specific Separation Efficiency Index as the main evaluation criterion for the summary analysis, even though the equipment-specific partition curve performance characteristics are the preferred approach. The rationale was that:

(1) while the partition curves generated from the data points seemed to be generally smooth, the inherent difficulty in performing washability analysis on coal as fine as 48 x 500 mesh cyclone feed, particularly the $200 \times 500$ mesh fraction, makes for some questionable results and inconsistencies,

(2) partition curves were generated only for selected tests, and some of those ended up being unusable, while the SEI can be applied to the entire set of tests, thereby providing a better picture of the effects of the variables.

Thus, the results will be discussed on the basis of SEI, using the partition curve performance characteristics as reinforcement where possible. We recognize that the SEI has its own limitations--for example, its optimum value based on the washability analysis varies with the specific gravity of separation somewhat. But on balance, we feel that the SEI is a good measure that is indicative of the sharpness of separation when compared on results from a single coal. Higher numbers indicate a sharper separation, with an SEI of about 900 being the optimum for the 48 x 200 mesh size fraction according to its washability analysis, and an SEI of about 1200 being the optimum for the $200 \times 500$ mesh size fraction. 


\section{Test Results}

For each of the two Phases of testing, there are three tables in the Appendix that summarize the results. The first of the three, entitled Separation Efficiency (A1 and A4), presents the results from the direct analysis of the cyclone products for ash, sulfur, yield, Btu recovery, ash and sulfur reduction, and includes a calculation of the Separation Efficiency Index (SEI).

The second table in the set is entitled QA/QC Results (A2 and A5) and presents the results of the duplicate tests that were conducted to determine repeatability and to serve as a check on the test procedures.

The third table in the set is entitled Partition Curve Results (A3 and A6) and is a summary of the performance characteristics of those selected tests that were subjected to float-sink analysis in order to formulate a partition curve to determine Ep and SG50.

In order to assist in analyzing the data, Tables 7 and 8 were constructed, as shown below. These tables show which tests can be compared on an equal basis when trying to isolate the effects of a certain variable. They can be used with the SEI, which has been included in the tables, or any other measurement of performance one desires such as Ep, SG50, SG offset, pyritic sulfur reduction, etc. It may be useful to review the data in relation to that of recent publications on the subject (15).

Information from all of these tables was used in analyzing and reporting the following results.

Table 7. Guide to Analyzing the Test Results From Phase I--Test Numbers and SEIs (48x200 at the top; $200 \times 500$ at the bottom)

Effect of Medium Density (Going Across the Table), and the Effect of Magnetite Grade (Going Down)

\begin{tabular}{|c|c|c|c|c|c|c|c|}
\hline & & & 20 & & & & 40 \\
\hline 0.120 & K & & & 1-1 & $\begin{array}{l}566 \\
546\end{array}$ & $1-2$ & $\begin{array}{l}892 \\
656\end{array}$ \\
\hline Inlet & L & & & $1-4$ & $\begin{array}{l}811 \\
945\end{array}$ & $1-5$ & $\begin{array}{l}890 \\
906\end{array}$ \\
\hline 0.625 & $60 X$ & & & $1-15$ & $\begin{array}{l}721 \\
841\end{array}$ & 1-16 & $\begin{array}{l}864 \\
899\end{array}$ \\
\hline Apex & M & $1-11$ & $\begin{array}{l}227 \\
612\end{array}$ & $1-12$ & $\begin{array}{l}563 \\
678\end{array}$ & $1-13$ & $\begin{array}{l}720 \\
590\end{array}$ \\
\hline 0.120 & K & & & & & $1-3$ & $\begin{array}{l}836 \\
666\end{array}$ \\
\hline Inlet & L & & & & & $1-7$ & $\begin{array}{l}743 \\
595\end{array}$ \\
\hline 0.875 & $60 X$ & & & & & $1-17$ & $\begin{array}{l}576 \\
417\end{array}$ \\
\hline Apex & M & & & & & $1-14$ & $\begin{array}{l}278 \\
228\end{array}$ \\
\hline
\end{tabular}

Effect of Apex Size

\begin{tabular}{|l|l|l|l|l|l|l|}
\cline { 2 - 7 } \multicolumn{2}{c|}{} & \multicolumn{2}{c|}{0.625} & \multicolumn{2}{c|}{0.875} & \multicolumn{2}{c|}{1.000} \\
\hline \hline K & $1-2$ & 892 & $1-3$ & 836 & & \\
\hline L & $1-5$ & 890 & $1-7$ & 743 & $1-6$ & 698 \\
& & 906 & & 595 & & 454 \\
\hline $60 X$ & $1-16$ & 864 & $1-17$ & 576 & & \\
& & 899 & & 417 & & \\
\hline M & $1-13$ & 720 & $1-14$ & 278 & & \\
& & 590 & & 228 & & \\
\hline
\end{tabular}

Duplicate Tests to Determine Repeatability (Test 8 Products Were Split into 3 Sets of Samples)

\begin{tabular}{|l|l|l|l|l|l|l|l|l|l|}
\hline $1-5$ & 890 & $1-8 \mathrm{~A}$ & 855 & $1-8 \mathrm{~B}$ & 858 & $1-8 \mathrm{C}$ & 847 & $1-10$ & 763 \\
& 906 & & 935 & & 909 & & 887 & & 929 \\
\hline
\end{tabular}


Table 8. Guide to Analyzing the Test

Results From Phase II--Test Numbers

and SEIs (48x200 at the top; 200x500 at the

bottom)

Effect of Apex Size

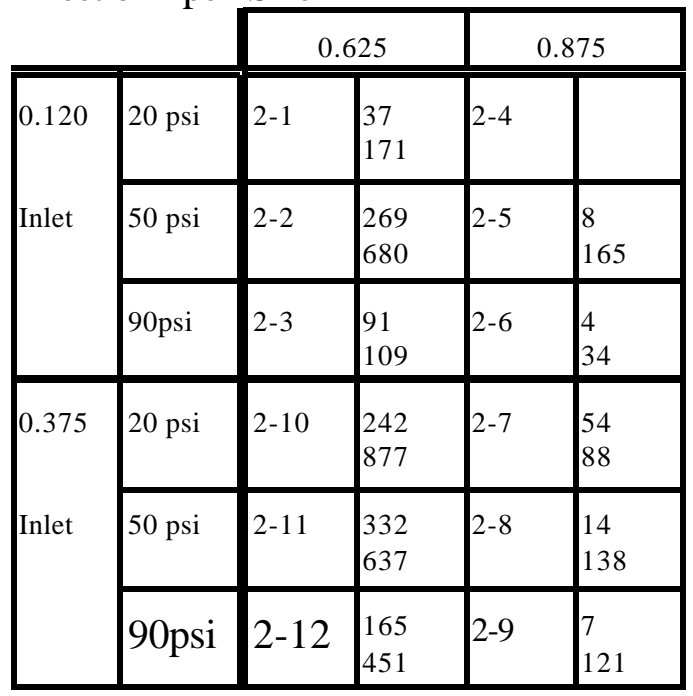

Effect of Inlet Size

\begin{tabular}{|c|c|c|c|c|c|}
\hline & & & 20 & & 375 \\
\hline 1.30 & $20 \mathrm{psi}$ & $2-16$ & $\begin{array}{l}573 \\
390\end{array}$ & 2-13 & $\begin{array}{l}773 \\
215\end{array}$ \\
\hline M.Den. & $50 \mathrm{psi}$ & 2-17 & $\begin{array}{l}757 \\
681\end{array}$ & 2-14 & $\begin{array}{l}784 \\
1193\end{array}$ \\
\hline & $80 \mathrm{psi}$ & $2-18$ & $\begin{array}{l}826 \\
1068\end{array}$ & 2-15 & $\begin{array}{l}903 \\
1187\end{array}$ \\
\hline 1.20 & $20 \mathrm{psi}$ & $2-1$ & \begin{tabular}{|l}
37 \\
171
\end{tabular} & $2-10$ & $\begin{array}{l}242 \\
877\end{array}$ \\
\hline M. Den. & $50 \mathrm{psi}$ & $2-2$ & $\begin{array}{l}269 \\
680\end{array}$ & 2-11 & $\begin{array}{l}332 \\
637\end{array}$ \\
\hline & $80 \mathrm{psi}$ & $2-3$ & $\begin{array}{l}91 \\
109\end{array}$ & 2-12 & $\begin{array}{l}165 \\
451\end{array}$ \\
\hline
\end{tabular}

Effect of Medium Density

\begin{tabular}{|c|c|c|c|c|c|}
\hline & & & .20 & & 30 \\
\hline 0.375 & 20 psi & $2-10$ & $\begin{array}{l}242 \\
877\end{array}$ & $2-13$ & $\begin{array}{l}773 \\
215\end{array}$ \\
\hline Inlet & $50 \mathrm{psi}$ & $2-11$ & $\begin{array}{l}332 \\
637\end{array}$ & $2-14$ & $\begin{array}{l}784 \\
1193\end{array}$ \\
\hline & 80/90psi & $2-12$ & $\begin{array}{l}165 \\
451\end{array}$ & $2-15$ & $\begin{array}{l}903 \\
1187\end{array}$ \\
\hline 0.120 & 20 psi & $2-1$ & \begin{tabular}{|l}
37 \\
171
\end{tabular} & $2-16$ & $\begin{array}{l}573 \\
390\end{array}$ \\
\hline Inlet & $50 \mathrm{psi}$ & $2-2$ & $\begin{array}{l}269 \\
680\end{array}$ & 2-17 & $\begin{array}{l}757 \\
681\end{array}$ \\
\hline & 80/90psi & $2-3$ & $\begin{array}{l}91 \\
109\end{array}$ & $2-18$ & $\begin{array}{l}826 \\
1068\end{array}$ \\
\hline
\end{tabular}

Effect of Inlet Pressure and Cyclone Geometry

\begin{tabular}{|c|c|c|c|c|c|c|c|c|}
\hline & & & & & & & & 190 \\
\hline 1.20 & $\begin{array}{l}\text { Small } \\
\text { Inlet }\end{array}$ & $\begin{array}{l}\text { Small } \\
\text { Apex }\end{array}$ & 2-1 & $\begin{array}{l}37 \\
171\end{array}$ & $2-2$ & $\begin{array}{l}269 \\
680\end{array}$ & $2-3$ & $\begin{array}{l}91 \\
109\end{array}$ \\
\hline M.D & $\begin{array}{l}\text { Small } \\
\text { Inlet }\end{array}$ & $\begin{array}{l}\text { Large } \\
\text { Apex }\end{array}$ & $2-4$ & & $2-5$ & $\begin{array}{l}8 \\
165\end{array}$ & $2-6$ & $\begin{array}{l}4 \\
34\end{array}$ \\
\hline & $\begin{array}{l}\text { Large } \\
\text { Inlet }\end{array}$ & $\begin{array}{l}\text { Large } \\
\text { Apex }\end{array}$ & 2-7 & $\begin{array}{l}54 \\
88\end{array}$ & $2-8$ & $\begin{array}{l}14 \\
138\end{array}$ & $2-9$ & $\begin{array}{l}7 \\
121\end{array}$ \\
\hline & $\begin{array}{l}\text { Large } \\
\text { Inlet }\end{array}$ & $\begin{array}{l}\text { Small } \\
\text { Apex }\end{array}$ & $2-10$ & $\begin{array}{l}242 \\
877\end{array}$ & $2-11$ & $\begin{array}{l}332 \\
637\end{array}$ & 2-12 & $\begin{array}{l}165 \\
451\end{array}$ \\
\hline 1.30 & $\begin{array}{l}\text { Large } \\
\text { Inlet }\end{array}$ & $\begin{array}{l}\text { Small } \\
\text { Apex }\end{array}$ & 2-13 & $\begin{array}{l}773 \\
215\end{array}$ & 2-14 & $\begin{array}{l}784 \\
119 \\
3\end{array}$ & 2-15 & $\begin{array}{l}903 \\
1187\end{array}$ \\
\hline M.D & $\begin{array}{l}\text { Small } \\
\text { Inlet }\end{array}$ & $\begin{array}{l}\text { Small } \\
\text { Apex }\end{array}$ & $2-16$ & $\begin{array}{l}573 \\
390\end{array}$ & $2-17$ & $\begin{array}{l}757 \\
681\end{array}$ & $2-18$ & $\begin{array}{l}826 \\
1068\end{array}$ \\
\hline
\end{tabular}

Duplicate Tests to Determine Repeatability

\begin{tabular}{|l|l|l|l|l|l|l|l|l|}
\hline $\begin{array}{l}60 \mathrm{X}, 50 \mathrm{psi}, \\
1.20 \mathrm{MD}, \\
625 \text { apex, } \\
120 \text { inlet }\end{array}$ & $2-2$ & 269 & $2-19$ & 386 & $2-21$ & 404 & $2-23$ & 367 \\
580 & & 714 & & 453 & & 536 \\
\hline
\end{tabular}




\section{Phase I Performance Evaluation}

The data generated from the Phase I testing produced the following results:

\section{Effect of Magnetite Grade}

(1) For both size fractions, for a given set of operating conditions, the Grade M magnetite almost always produced the worst separations in terms of the SEI and Ep. The Grade M tests at medium densities of 1.30 and 1.40 were marked by a visually evident increase in slurry viscosity, that likely inhibited the efficiency of the separation. However, the separation achieved using the Grade M magnetite at a lower medium density of 1.20 was nearly comparable to that achieved using the Grade L and 60X magnetites.

(2) For both size fractions, at both a 1.30 and 1.40 medium density, the Grade L and 60X magnetites produced the best results in terms of the calculated separation efficiency, probable error, and SG50 values when using the 0.625 inch apex. However, Grade K produced similar results for the $48 \times 200$ mesh fraction at a 1.40 medium density in terms of separation efficiency for both the 0.625 and 0.875 inch apexes.

\section{Effect of Apex Size}

(1) For both size fractions, for this coal and for a given grade of magnetite, the use of the smaller 0.625 apex diameter almost always produced the lowest probable error values and the highest separation efficiency indices (SEI). The exception was Grade K magnetite, which showed little effect with changing apex size. This effect increased as magnetite fineness increased.

(2) As expected, the larger 0.875 apex resulted in lower SG50s at the expense of higher Eps.

\section{Test Repeatability}

(1) The three replicate tests (1-5, 1-8, and 1-10), as well as the triplicate sampling within a single test (1-8 A, B, and C), indicate excellent repeatability in terms of setting test conditions, sampling protocols, and analytical techniques. Obtaining similar conditions and results among independent batch cyclone tests where each test is run with a separate charge of coal and magnetite for a relatively short time is very difficult. For the $200 \times 500$ mesh fraction, SG50s varied from 1.95 to 2.04, and Eps varied from 0.129 to 0.158. Separation efficiency indices for both size fractions were also very similar.

\section{Phase I Performance Summary}

(1) At the constant conditions of 90 psi inlet pressure with a 0.120 inch inlet, the best results for the $48 \times 200$ mesh fraction were obtained using the smallest apex diameter (0.625) at a medium density of 1.30 or 1.40 . For tests run at these conditions, the Grade K, L, and 60X magnetites all produced roughly the same quality of separation efficiency with the better tests achieving ash reductions of $40-50 \%$ at greater than $95 \%$ Btu recovery. 
(2) Also for the $48 \times 200$ mesh size fraction, from the partition curve analyses completed, Test 116 with Grade 60X magnetite, a 0.625 apex, at a medium density of 1.40 produced the lowest Ep value at 0.061 with a SG50 of 1.64 .

(3) At the constant conditions of 90 psi inlet pressure with a 0.120 inch inlet, for the $200 \times 500$ mesh size fraction, the best results in terms of separation efficiency and Ep were tests 1-4, 1-5, $1-15$, and 1-16, run using the 0.625 apex at a 1.30 or 1.40 medium density, and Grades L or 60X magnetites. Probable error values ranged from 0.129 to 0.168 with D50s from 1.73 to 2.03. The Grade K magnetite produced comparable probable errors of 0.155 to 0.160 , but at high D50s of about 2.25.

(4) At the best conditions referenced above, pyritic sulfur reduction was excellent. For example, in test $1-4$ for the $48 \times 200$ mesh size fraction, the pyritic sulfur was reduced from $1.78 \%$ to $0.71 \%$, a $60 \%$ reduction at a $94 \%$ Btu recovery. For the $200 \times 500$ mesh size fraction, the pyritic sulfur was reduced from $2.18 \%$ to $0.57 \%$, a $74 \%$ reduction at a $95 \%$ Btu recovery.

\section{Phase II Performance Evaluation}

The data generated from the Phase II testing produced the following results:

\section{Effect of Apex Size}

(1) As shown in Phase I, for this coal and for a given set of operating conditions, the smaller apex opening always produced significantly higher SEI values than the larger apex opening for both size fractions. Partition curve data was not available from any of the large apex tests, so no comparisons for Ep could be made.

\section{Effect of Inlet Size}

(1) For a given operating pressure, the larger inlet (0.375) generally produced only slightly higher SEI values than the smaller inlet (0.120) for the $48 \times 200$ mesh size fraction. However, for the 200 x 500 mesh size fraction, this improvement was more pronounced at certain inlet pressures, depending on the medium density.

(2) For the $48 \times 200$ mesh size fraction, comparable Ep values were achieved for either inlet size with Ep values ranging from 0.034 to 0.064 across the entire scope of operating conditions tested. Also, there was no apparent effect on SG50.

(3) For the $200 \times 500$ mesh size fraction, approximately equal Ep values of 0.118 and 0.135 were generated for the large and small inlet openings, respectively, as well as fairly equal SG50s of 1.69 and 1.74 , respectively. 


\section{Effect of Medium Density}

(1) For the $48 \times 200$ mesh size fraction, any test run at a medium density of 1.30 produced a higher SEI value than any test run using a medium density of 1.20 . For the 1.30 medium density tests, the SEIs ranged from approximately 570 to 900 compared to a range of 40 to 330 for the 1.20 density tests. As mentioned earlier, this is partially due to the lower SG50s from the 1.20 medium, producing inherently lower SEI values.

(2) For the $200 \times 500$ mesh fraction, for a given set of operating conditions, the 1.30 medium produced a higher SEI value than the 1.20 medium for most of the tests. Only when using the large inlet and a 20-psi inlet pressure did the 1.20 medium density produce a significantly better separation, probably because the less severe conditions allowed for better stability of the more dilute medium.

(3) Medium density had little discernable impact on Ep or SG50 values for either size fraction.

\section{Effect of Cyclone Geometry and Inlet Pressure}

(1) For both size fractions, the large inlet/small apex cyclone configuration generally produced higher SEI values compared to any of the other three configurations tested. However, in four cases the SEI value for the small inlet/small apex combination, at either a 50- or 90-psi inlet pressure, approached (but never quite equaled) the SEI value obtained with the large inlet/small apex. As discussed earlier, tests with the large apex were generally inferior.

(2) For the $200 \times 500$ mesh size fraction, the three highest SEI values were produced using a 1.30 medium density at either a 50- or 90-psi inlet pressure. This is similar to the 48 x 200 mesh size fraction where the two best runs were produced at a 90-psi inlet pressure using a 1.30 medium density.

(3) For the $200 \times 500$ mesh size fraction, the only test condition (2-10) under which 20-psi inlet pressure produced a higher or comparable SEI value than either the 50- or 90-psi inlet pressure was the one using the large inlet/small apex combination and a 1.20 medium density. This was discussed in number 2 in the above section on medium density.

(4) Little difference was found in Ep values for the 48 x 200 mesh size fraction, with Eps ranging from 0.034 to 0.064 . Inlet pressure had little effect on SG50s.

(5) For the $200 \times 500$ mesh size fraction, the tests run at a 1.20 medium density using the large inlet/small apex configuration produced essentially the same Ep values no matter what the inlet pressure. However, for the tests run at a 1.30 medium density, Ep values for the $200 \times 500$ mesh size fraction increased significantly as inlet pressure was decreased from 90 psi to $50 \mathrm{psi}$ to 20 psi. SG50s increased only slightly with increasing inlet pressure. 


\section{Test Repeatability}

(1) Repeatability, as indicated by Tests 2-2, 2-19, 2-21, and 2-23, was fairly good for both size fractions in terms of Ep, SG50, and SEI, but the results showed more scatter than in Phase I. One exception was the Ep for 2-21 which was unusually high, probably due to experimental error.

\section{Phase II Performance Summary}

(1) The best results in Phase II for the $48 \times 200$ mesh size fraction were those tests run with a 1.30 medium density, using a small or large inlet, small apex, at either 20,50 or 90 psi inlet pressure (2-13, 2-14, 2-15, 2-16, 2-17, 2-18). Eps were between 0.034 and 0.051 with SG50s between 1.47 and 1.53. Similar tests at a 1.20 medium density were almost as good, but with lower SG50s (1.33 to 1.34) and thus, lower SEIs.

(2) The best results in Phase II for the 200 x 500 mesh size fraction were those tests run with a 1.30 medium density, using a large inlet and small apex, at either 50 or 90 psi inlet pressure (214, 2-15), based on SEI and Ep.

\section{Conclusions}

(1) The results confirmed those found by Custom Coals during their pilot plant study in that the Grade $\mathrm{M}$ magnetite is too fine and does not provide for separations as sharp as the other coarser grades of magnetite. This appears to be due to the high viscosities created by the ultrafine magnetite particles, particularly for medium densities 1.30 and greater.

(2) Phase I testing resulted in the conclusion that any of the three coarser grades of magnetite (K, L, 60X) would be quite suitable for making very good separations in the $48 \times 200$ mesh size range.

(3) Phase I testing results also showed that Grades L and 60X magnetites produced better separations on the $200 \times 500$ mesh size fraction than the Grade K magnetite.

(4) Both phases of testing confirmed that the best operating conditions for this coal and for these SG50s include the use of the 0.625 apex diameter as opposed to the larger ones. Phase II testing results further showed that the large inlet/small apex cyclone configuration produced the best separations. The choice of orifices in any situation is somewhat dependent on the reject yield.

(5) Phase II testing results showed that when using the 60X magnetite, the tests with the higher 50and 90-psi inlet pressures consistently produced superior separations to those at $20 \mathrm{psi}$. 
(6) Phase II testing results showed that varying the medium density from 1.20 to 1.30 when using the 60X magnetite did not produce any discernable impact on probable error for either size fraction.

(7) Based on both phases of testing, the optimum set of operating conditions includes a Grade L or $60 \mathrm{X}$ magnetite, an inlet feed pressure of greater than 20 psi (possibly as high as 50-90 psi), and a cyclone configuration consisting of a large diameter inlet and a small apex orifice (in this case, for a four-inch diameter cyclone, a $0.375 \mathrm{in}^{2}$ inlet and a 0.625 -inch diameter apex orifice worked best). Under these conditions, excellent separations can be achieved, with probable errors in the approximate range of 0.035 to 0.050 for the $48 \times 200$ mesh size fraction, and in the approximate range of 0.120 to 0.140 for the $200 \times 500$ mesh size fraction.

(8) Finally, the results reaffirm that sharp separations can be made on finer coal, such as $48 \times 500$ mesh, than is conventionally cleaned by using a "semi-micronized" magnetite that is much finer than conventional magnetite, but is not completely in the 0-5 micron range. For example, conventional Grade B \& E magnetites may have a D50 particle size of 11 to 14 microns, and are used to clean coal size fractions from 1 or $1 / 2$ inches top size down to 28 or 100 mesh, with overall Eps probably in the range of 0.020 to 0.060 , depending on size consist and operating conditions.

However, in this study and the Custom Coals pilot plant study referenced, it was shown that a significantly finer 48 by 500 mesh feed coal could be cleaned using magnetite with a D50 particle size of 4 to 9 microns (roughly half the size of conventional magnetite) with overall Eps in the range of 0.060 to 0.090 . In addition, excellent pyritic sulfur reduction was achieved even down to 500 mesh. It is also important to note that the Custom Coals study demonstrated that magnetite in this size range could be easily recovered with conventional magnetic separator circuits.

\section{References}

(1) Klima, M.S., C.P. Maronde, and R.P. Killmeyer, "Fine Coal Cleaning via the Micro-Mag Process," U.S. Patent No. 5,022,892 (1991).

(2) Klima, M.S., C.P. Maronde and R.P. Killmeyer, "A Preliminary Investigation of Fine-Coal Cleaning Via the Micro-Mag Process," proceedings of Coal Prep '89, Lexington, KY, May 1989.

(3) Klima, M.S., R.P. Killmeyer, "Effect of Operating Conditions on Micronized-Magnetite Cycloning Performance," Proceedings of Coal Prep '90, Cincinnati, Ohio, May 1990.

(4) Klima, M.S., and R.P. Killmeyer, "Development of a Micronized Magnetite Cycloning Process," XI International Coal Preparation Congress, Tokyo, Japan, October 1990. 
(5) Miller, K.J., M.S. Klima, R.P. Killmeyer, "Selection and Production of Medium Solids for the Micro-Mag Process," U.S. DOE Topical Report DOE/PETC/TR-91/5, April 1991.

(6) Klima, M.S., R.P. Killmeyer, "Baseline Performance Evaluation of Micronized-Magnetite Cycloning," U.S. DOE Topical Report DOE/PETC/TR-91/9, June 1991.

(7) Klima, M.S., R.P. Killmeyer, "An Update on the Development of the Micro-Mag Process," SME Annual Meeting Preprint, Phoenix, AZ, February 1992.

(8) Klima, M.S., R.P. Killmeyer, "Baseline Performance Evaluation of Micronized-Magnetite Recovery Using Conventional Wet-Drum and High-Gradient Magnetic Separators," U.S. DOE Topical Report DOE/PETC/TR-92/10, June 1992.

(9) Klima, M.S., and R.P. Killmeyer, "Performance Evaluation of Micronized-Magnetite Cycloning at High Relative Densities of Separation," U.S. DOE Topical Report DOE/PETC/TR-92/11, July 1992.

(10) Klima, M.S., and R.P. Killmeyer, "An Evaluation of a Laboratory Wet-Drum Magnetic Separator for Micronized-Magnetite Recovery," Coal Preparation -- A Multinational Journal, Vol. 16, Numbers 3-4, 1995.

(11) Maronde, C.P., R.P. Killmeyer, and P.J. Suardini (Custom Coals International), "Integrated Continuous Testing of the Micronized-Magnetite Beneficiation Process in PETC's Coal Preparation Process Research Facility," Proceedings of the High Efficiency Preparation Symposium, SME Annual Meeting, Denver, CO, March 1995.

(12) Torak, E.R. and P.J. Suardini (Custom Coals International), "Bench-Scale Testing of the Micronized-Magnetite Process," Final DOE Report, Contract No. DE-AC22-93PC92206, November 1997.

(13) Paul, A.D., C.P. Maronde, and R.P. Killmeyer, "Evaluation of Mathematical Functions for Representing Partition Data -- A Case Study," XIII International Coal Preparation Congress, Brisbane Australia, October 1998.

(14) Suardini, P. J. (Process Technology, Inc.), "Improving Laboratory Float/Sink Methods for FineCoal Liberation Studies,” Final DOE SBIR Phase I Report, Project No. DE-FG02-91ER81203, May 1992.

(15) He, Y. B., and J. S. Laskowski, "Dense Medium Cyclone Separation of Fine Particles Parts I and II,” Coal Preparation -- A Multinational Journal, Vol. 16, Numbers 1-2, 1995. 


\section{Appendix}

Table A1. PHASE I TEST RESULTS -- Separation Efficiency

\begin{tabular}{|c|c|c|c|c|c|c|c|c|c|c|c|c|c|c|c|c|}
\hline $\begin{array}{c}\text { TEST NO. } \\
\text { and } \\
\text { CONDITIONS }\end{array}$ & $\begin{array}{l}\text { SIZE, } \\
\text { MESH }\end{array}$ & YIELD, \% & $\underset{\%}{\mathrm{FEED} \text { ASH, }}$ & $\begin{array}{l}\text { PROD. } \\
\text { ASH, } \%\end{array}$ & $\begin{array}{l}\text { REFUSE } \\
\text { ASH, \% }\end{array}$ & $\begin{array}{l}\text { FEED } \\
\text { rSULFUR, } \\
\%\end{array}$ & $\begin{array}{l}\text { PROD. } \\
\text { TSULFUR, } \\
\%\end{array}$ & $\begin{array}{c}\text { REFUSE } \\
\text { ISULFUR, } \\
\%\end{array}$ & \begin{tabular}{|c|} 
FEED \\
PSULFUR, \\
$\%$
\end{tabular} & $\begin{array}{c}\text { PROD. } \\
\text { PSULFUR, } \\
\%\end{array}$ & $\begin{array}{c}\begin{array}{c}\text { REFUSE } \\
\text { PSULFUR, } \\
\%\end{array} \\
\%\end{array}$ & $\begin{array}{l}\text { BTU } \\
\text { RECOV., \% }\end{array}$ & $\underset{\%}{\text { ASH RED., }}$ & $\begin{array}{l}\text { TOT. S. } \\
\text { RED., \% }\end{array}$ & $\begin{array}{l}\text { PYR. S. } \\
\text { RED., } \%\end{array}$ & $\begin{array}{l}\text { SEP. EFF } \\
\text { INDEX }\end{array}$ \\
\hline $1-1$ & $48 \times 200$ & 87.26 & 12.37 & 7.28 & 47.26 & 3.56 & 3.06 & 6.98 & 1.51 & 0.89 & 5.77 & 92.33 & 41.16 & 14.03 & 41.13 & 566 \\
\hline $\mathrm{K}, .12,1.30, .625,90$ & $200 \times 500$ & 86.76 & 11.91 & 7.00 & 44.05 & 3.21 & 2.85 & 5.54 & 1.31 & 0.76 & 4.94 & 91.59 & 41.20 & 11.11 & 42.14 & 546 \\
\hline $1-2$ & $48 \times 200$ & 92.23 & 12.62 & 7.54 & 72.90 & 3.69 & 3.11 & 10.52 & 1.68 & 0.98 & 9.94 & 97.59 & 40.25 & 15.62 & 41.53 & 892 \\
\hline $\mathrm{K}, .12,1.40, .625,90$ & $200 \times 500$ & 90.74 & 12.61 & 8.00 & 57.80 & 3.19 & 3.01 & 4.92 & 1.20 & 0.85 & 4.67 & 95.53 & 36.57 & 5.55 & 29.39 & 656 \\
\hline $1-3$ & $48 \times 200$ & 93.04 & 10.21 & 6.56 & 58.97 & 3.27 & 2.87 & 8.66 & 1.39 & 0.87 & 8.40 & 96.82 & 35.74 & 12.31 & 37.59 & 836 \\
\hline $\bar{K}, 12,1.40, .875,90$ & $200 \times 500$ & 88.35 & 10.60 & 6.02 & 45.35 & 3.61 & 2.65 & 10.87 & 1.74 & 0.64 & $\overline{10.12}$ & 92.88 & 43.22 & 26.54 & 63.31 & 666 \\
\hline $1-4$ & $48 \times 200$ & 88.02 & 11.82 & 5.96 & 54.91 & 3.69 & 2.81 & 10.17 & 1.78 & 0.71 & 9.67 & 93.87 & 49.59 & 23.88 & 60.19 & 811 \\
\hline$, .12,1.30, .625,90$ & $200 \times 500$ & 89.40 & 11.20 & 5.56 & 58.80 & 4.09 & 2.63 & 16.41 & 2.18 & 0.57 & 15.79 & 95.08 & 50.37 & 35.71 & 73.89 & 945 \\
\hline $1-5$ & $48 \times 200$ & 91.90 & 11.60 & 6.81 & 65.93 & 3.73 & 2.97 & 12.38 & 1.56 & 0.78 & 10.36 & 96.88 & 41.29 & 20.42 & 49.87 & 890 \\
\hline$=, 12,1.40, .625,90$ & $200 \times 500$ & 90.80 & 11.00 & 6.02 & 60.10 & 3.93 & 2.69 & 16.16 & 1.92 & 0.55 & 15.48 & 95.88 & 45.25 & 31.54 & 71.41 & 906 \\
\hline $1-6$ & $48 \times 200$ & 84.17 & 12.63 & 5.86 & 48.62 & 3.74 & 2.79 & 8.76 & 2.30 & 0.78 & 10.36 & 90.69 & 53.60 & 25.30 & 66.04 & 698 \\
\hline$, .12,1.40,1.00,90$ & $200 \times 500$ & 74.48 & 11.48 & 4.99 & 30.44 & 4.03 & 2.54 & 8.36 & 4.36 & 0.55 & 15.48 & 79.95 & 56.55 & 36.90 & 87.39 & 454 \\
\hline $1-7$ & $48 \times 200$ & 84.67 & 13.74 & 6.27 & 55.03 & 3.74 & 2.88 & 8.52 & 2.05 & 0.78 & 9.05 & 92.01 & 54.38 & 23.09 & 61.91 & 743 \\
\hline$=, 12,1.40, .875,90$ & $200 \times 500$ & 77.55 & 13.41 & 5.37 & 41.18 & 4.33 & 2.60 & 10.31 & 2.45 & 0.53 & 9.09 & 84.75 & 59.95 & 39.97 & 78.38 & 595 \\
\hline $1-8 \mathrm{~A}$ & $48 \times 200$ & 88.65 & 13.87 & 7.00 & 67.51 & 4.03 & 3.02 & 11.92 & 2.04 & 0.88 & 11.08 & 95.72 & 49.52 & 25.06 & 56.81 & 855 \\
\hline$=, .12,1.40, .625,90$ & $200 \times 500$ & 89.93 & 11.83 & 6.05 & 62.87 & 4.13 & 2.73 & 16.50 & 2.23 & 0.64 & 16.27 & 95.72 & 48.85 & 33.90 & 71.29 & 935 \\
\hline $1-8 \mathrm{~B}$ & $48 \times 200$ & 91.90 & 11.89 & 7.10 & 66.25 & 3.68 & 2.99 & 11.48 & 1.65 & 0.85 & 10.73 & 96.90 & 40.29 & 18.70 & 48.49 & 858 \\
\hline$=, .12,1.40, .625,90$ & $200 \times 500$ & 91.91 & 10.78 & 6.27 & 62.04 & 3.86 & 2.74 & 16.63 & 1.89 & 0.67 & 15.77 & 96.56 & 41.85 & 29.08 & 64.58 & 909 \\
\hline $1-8 \mathrm{C}$ & $48 \times 200$ & 89.72 & 13.22 & 7.08 & 66.82 & 3.85 & 2.93 & 11.87 & 1.86 & 0.85 & 10.68 & 96.07 & 46.45 & 23.88 & 54.31 & 847 \\
\hline$, .12,1.40, .625,90$ & $200 \times 500$ & 89.51 & 12.19 & 6.30 & 62.42 & 4.24 & 2.75 & 16.96 & 2.25 & 0.63 & 16.11 & 95.51 & 48.31 & 35.15 & 72.05 & 887 \\
\hline $1-9$ & $48 \times 200$ & 88.45 & 12.86 & 6.64 & 60.51 & 3.83 & 2.89 & 11.02 & 1.80 & 0.78 & 9.63 & 94.77 & 48.37 & 24.52 & 56.72 & 806 \\
\hline$, .375,1.40, .625$ & $200 \times 500$ & 87.43 & 11.66 & 6.25 & 49.28 & 4.18 & 2.84 & 13.49 & 2.19 & 0.71 & 12.50 & 92.78 & 46.39 & 32.04 & 67.61 & 689 \\
\hline $1-10$ & $48 \times 200$ & 89.96 & 13.39 & 7.65 & 64.86 & 3.54 & 2.79 & 10.24 & 1.88 & 1.09 & 9.00 & 95.93 & 42.88 & 21.14 & 42.15 & 763 \\
\hline$, .12,1.40, .625,90$ & $200 \times 500$ & 89.93 & 11.77 & 6.07 & 62.71 & 4.04 & 2.55 & 17.37 & 2.42 & 1.02 & 14.94 & 95.74 & 48.44 & 36.92 & 57.88 & 929 \\
\hline $1-11$ & $48 \times 200$ & 41.90 & 14.18 & 3.97 & 21.54 & 3.71 & 2.50 & 4.58 & 1.98 & 0.73 & 2.89 & 46.88 & 72.00 & 32.59 & 63.22 & 227 \\
\hline $\begin{array}{c}\mathrm{M}, .12,1,20, .625 \\
90\end{array}$ & $200 \times 500$ & 78.08 & 11.67 & 4.67 & 36.61 & 4.07 & 2.34 & 10.22 & 2.33 & 0.71 & 8.08 & 84.27 & 59.99 & 42.47 & 69.47 & 612 \\
\hline $1-12$ & $48 \times 200$ & 80.66 & 11.64 & 5.40 & 37.66 & 3.41 & 2.58 & 6.87 & 1.77 & 0.91 & 5.38 & 86.36 & 53.60 & 24.33 & 48.72 & 563 \\
\hline $\mathrm{M}, .12,1.30, .625$ & $200 \times 500$ & 85.59 & 10.98 & 5.50 & 43.56 & 3.71 & 2.37 & 11.68 & 2.27 & 0.91 & 10.32 & 90.86 & 49.93 & 36.15 & 59.84 & 678 \\
\hline $1-13$ & $48 \times 200$ & 86.67 & 13.44 & 6.81 & 56.55 & 3.63 & 2.82 & 8.91 & 3.35 & 2.77 & 7.13 & 93.31 & 49.33 & 22.35 & 17.34 & 720 \\
\hline $\begin{array}{c}\mathrm{M}, .12,1.40, .625 \\
90\end{array}$ & $200 \times 500$ & 87.24 & 11.55 & 6.66 & 45.01 & 2.24 & 0.67 & 13.00 & 1.93 & 0.68 & 10.46 & 92.07 & 42.35 & 70.13 & 64.73 & 590 \\
\hline $1-14$ & $48 \times 200$ & 72.32 & 10.50 & 5.87 & 22.58 & 3.46 & 2.84 & 5.07 & 1.43 & 0.70 & 3.34 & 76.06 & 44.07 & 17.85 & 51.07 & 278 \\
\hline $\mathrm{M}, .12,1.40, .875$ & $200 \times 500$ & 65.64 & 11.73 & 6.34 & 22.03 & 4.20 & 2.86 & 6.77 & 2.24 & 0.69 & 5.21 & 69.65 & 45.96 & 31.96 & 69.24 & 228 \\
\hline $1-15$ & $48 \times 200$ & 81.71 & 12.91 & 5.31 & 46.84 & 3.47 & 2.69 & 6.97 & 1.59 & 0.52 & 6.37 & 88.84 & 58.86 & 22.54 & 67.29 & 721 \\
\hline $60 \mathrm{X}, 12,1.30,625,90$ & $200 \times 500$ & 78.47 & 12.56 & 5.62 & 60.20 & 3.83 & 2.55 & 8.48 & 2.01 & 0.45 & 7.71 & 93.49 & 55.27 & 33.36 & 77.65 & 841 \\
\hline
\end{tabular}




\begin{tabular}{|c|c|c|c|c|c|c|c|c|c|c|c|c|c|c|c|c|}
\hline $\begin{array}{c}\text { TEST NO. } \\
\text { and } \\
\text { CONDITIONS }\end{array}$ & $\begin{array}{l}\text { SIZE, } \\
\text { MESH }\end{array}$ & YIELD, \% & $\underset{\%}{\text { FEED ASH. }}$ & $\begin{array}{l}\text { PROD. } \\
\text { ASH, } \%\end{array}$ & $\begin{array}{l}\text { REFUSE } \\
\text { ASH, } \%\end{array}$ & $\begin{array}{c}\text { FEED } \\
\text { TSULFUR, } \\
\%\end{array}$ & $\begin{array}{l}\text { PROD. } \\
\text { T SULFUR, } \\
\%\end{array}$ & $\begin{array}{l}\text { REFUSE } \\
\text { TSULFUR, } \\
\%\end{array}$ & $\begin{array}{c}\text { FEED } \\
\text { SULFUR, } \\
\%\end{array}$ & $\begin{array}{l}\text { PROD. } \\
\text { PSULFUR, } \\
\%\end{array}$ & $\begin{array}{l}\text { REFUSE } \\
\text { PSULFUR, } \\
\%\end{array}$ & $\begin{array}{l}\text { BTU } \\
\text { RECOV., \% }\end{array}$ & $\underset{\%}{\text { ASHRED., }}$ & $\begin{array}{l}\text { TOT. S. } \\
\text { RED., \% }\end{array}$ & $\begin{array}{l}\text { PYR. S. } \\
\text { RED., } \%\end{array}$ & $\begin{array}{l}\text { SEP. EFF. } \\
\text { INDEX }\end{array}$ \\
\hline $1-16$ & $48 \times 200$ & 88.70 & 12.40 & 6.24 & 60.77 & 3.69 & 2.95 & 9.51 & 1.63 & 0.75 & 8.51 & 94.94 & 49.69 & 20.08 & 53.90 & 864 \\
\hline $60 \mathrm{X}, 12,1.40,625,90$ & $200 \times 500$ & 82.15 & 11.69 & 6.62 & 72.46 & 3.18 & 2.75 & 5.16 & 1.37 & 0.60 & $\overline{4.92}$ & 95.52 & 43.37 & 13.53 & 56.24 & 899 \\
\hline $1-17$ & $48 \times 200$ & 76.93 & 13.46 & 5.39 & 40.39 & 3.75 & 2.77 & 7.02 & 1.73 & 0.54 & 5.68 & 84.11 & 59.97 & 26.14 & 68.71 & 576 \\
\hline $\begin{array}{c}60 \mathrm{X}, .12,1.40 \\
.875,90\end{array}$ & $200 \times 500$ & 65.90 & 12.99 & 6.93 & 43.86 & 3.13 & 2.52 & 4.32 & 1.50 & 0.40 & 3.64 & 77.54 & 46.65 & 19.59 & 73.42 & 417 \\
\hline
\end{tabular}


Table A2. PHASE I QA/QC RESULTS

(GRADE L, 0.12 SQ IN INLET, 0.625" APEX, 1.40 MED DENSITY, \& 90 PSI INLET PRESSURE)

\begin{tabular}{|c|c|c|c|c|c|c|c|c|c|c|c|c|}
\hline \multirow[b]{3}{*}{$\begin{array}{c}\text { TEST } \\
\text { NO. }\end{array}$} & \multicolumn{12}{|c|}{ CYCLONE PERFORMANCE RESULTS } \\
\hline & \multicolumn{6}{|c|}{48 X 200 MESH FRACTION } & \multicolumn{6}{|c|}{200 X 500 MESH FRACTION } \\
\hline & $\begin{array}{l}\text { WEIGHT } \\
\text { YIELD } \\
(\%)\end{array}$ & $\begin{array}{c}\text { CLEAN } \\
\text { COAL } \\
\text { ASH } \\
(\%)\end{array}$ & $\begin{array}{c}\text { REFUSE } \\
\text { ASH } \\
(\%)\end{array}$ & Ep & SG50 & $\begin{array}{c}\text { SEPARATION } \\
\text { EFFICIENCY } \\
\text { INDEX }\end{array}$ & $\begin{array}{l}\text { WEIGHT } \\
\text { YIELD } \\
(\%)\end{array}$ & $\begin{array}{c}\text { CLEAN } \\
\text { COAL } \\
\text { ASH } \\
(\%)\end{array}$ & $\begin{array}{c}\text { REFUSE } \\
\text { ASH } \\
(\%)\end{array}$ & Ep & SG50 & $\begin{array}{c}\text { SEPARATION } \\
\text { EFFICIENCY } \\
\text { INDEX }\end{array}$ \\
\hline $1-5$ & 91.90 & 6.81 & 65.93 & 0.087 & 1.82 & 890 & 90.80 & 6.02 & 60.10 & 0.129 & 2.03 & 906 \\
\hline $1-8 A$ & 88.65 & 7.00 & 67.51 & --- & --- & 855 & 89.83 & 6.05 & 62.87 & 0.144 & 1.96 & 933 \\
\hline $1-8 B$ & 91.90 & 7.10 & 66.25 & --- & --- & 858 & 91.91 & 6.27 & 62.04 & 0.158 & 2.04 & 909 \\
\hline $1-8 C$ & 89.72 & 7.08 & 66.82 & 0.083 & 1.75 & 847 & 89.51 & 6.30 & 62.42 & 0.152 & 1.98 & 887 \\
\hline $1-10$ & 89.96 & 7.65 & 64.86 & --- & --- & 763 & 89.93 & 6.07 & 62.71 & 0.133 & 1.95 & 929 \\
\hline AVG & 90.43 & 7.13 & 66.27 & 0.085 & 1.79 & 841 & 90.40 & 6.14 & 62.03 & 0.143 & 1.99 & 913 \\
\hline ST DEV & 1.46 & 0.31 & 0.99 & 0.003 & 0.05 & 47 & 0.97 & 0.13 & 1.12 & 0.012 & 0.04 & 19 \\
\hline
\end{tabular}




\begin{tabular}{|c|c|c|c|c|c|c|c|c|c|}
\hline \multicolumn{10}{|c|}{ Table A3. PHASE I PARTITION CURVE RESULTS } \\
\hline \multirow{3}{*}{$\begin{array}{l}\text { TEST } \\
\text { NO. }\end{array}$} & \multicolumn{5}{|c|}{ OPERATING CONDITIONS } & \multicolumn{4}{|c|}{ CYCLONE PERFORMANCE } \\
\hline & \multirow{2}{*}{$\begin{array}{c}\text { MAGNETITE } \\
\text { GRADE }\end{array}$} & \multirow{2}{*}{$\begin{array}{c}\text { INLET } \\
\text { (SQ IN) }\end{array}$} & \multirow{2}{*}{$\begin{array}{c}\text { FEED } \\
\text { PRESSURE } \\
\text { (PSI) }\end{array}$} & \multirow{2}{*}{$\begin{array}{c}\text { MEDIUM } \\
\text { DENSITY } \\
(\mathrm{G} / \mathrm{CC})\end{array}$} & \multirow{2}{*}{$\begin{array}{c}\text { APEX } \\
\text { ORIFICE } \\
\text { (INCHES) }\end{array}$} & \multicolumn{2}{|c|}{$\begin{array}{c}48 \times 200 \\
\text { MESH }\end{array}$} & \multicolumn{2}{|c|}{$\begin{array}{c}200 \times 500 \\
\text { MESH }\end{array}$} \\
\hline & & & & & & Ep & SG50 & Ep & $\begin{array}{c}\text { SG5 } \\
0\end{array}$ \\
\hline $1-1$ & $\mathrm{~K}$ & 0.12 & 90 & 1.30 & 0.625 & --- & --- & 0.155 & 2.24 \\
\hline $1-2$ & $\mathrm{~K}$ & 0.12 & 90 & 1.40 & 0.625 & --- & --- & 0.160 & 2.25 \\
\hline $1-3$ & $\mathrm{~K}$ & 0.12 & 90 & 1.40 & 0.875 & --- & --- & 0.210 & 1.96 \\
\hline $1-4$ & $\mathrm{~L}$ & 0.12 & 90 & 1.30 & 0.625 & --- & --- & 0.134 & 2.03 \\
\hline $1-5$ & $\mathrm{~L}$ & 0.12 & 90 & 1.40 & 0.625 & 0.087 & 1.82 & 0.129 & 2.03 \\
\hline $1-6$ & $\mathrm{~L}$ & 0.12 & 90 & 1.40 & 1.00 & --- & --- & 0.177 & 1.63 \\
\hline $1-7$ & $\mathrm{~L}$ & 0.12 & 90 & 1.40 & 0.875 & --- & --- & 0.225 & 1.72 \\
\hline $1-8 \mathrm{~A}$ & $\mathrm{~L}$ & 0.12 & 90 & 1.40 & 0.625 & --- & --- & 0.144 & 1.96 \\
\hline $1-8 \mathrm{~B}$ & $\mathrm{~L}$ & 0.12 & 90 & 1.40 & 0.625 & --- & --- & 0.158 & 2.04 \\
\hline $1-8 \mathrm{C}$ & $\mathrm{L}$ & 0.12 & 90 & 1.40 & 0.625 & 0.083 & 1.75 & 0.152 & 1.98 \\
\hline $1-9$ & $\mathrm{~L}$ & 0.375 & 20 & 1.40 & 0.625 & 0.094 & 1.70 & 0.259 & 2.01 \\
\hline $1-10$ & $\mathrm{~L}$ & 0.12 & 90 & 1.40 & 0.625 & --- & --- & 0.133 & 1.95 \\
\hline $1-11$ & M & 0.12 & 90 & 1.20 & 0.625 & --- & --- & 0.152 & 1.62 \\
\hline $1-12$ & M & 0.12 & 90 & 1.30 & 0.625 & --- & --- & 0.220 & 1.76 \\
\hline $1-13$ & M & 0.12 & 90 & 1.40 & 0.625 & 0.107 & 1.66 & 0.237 & 2.06 \\
\hline $1-14$ & M & 0.12 & 90 & 1.40 & 0.875 & --- & --- & 0.346 & 1.63 \\
\hline $1-15$ & $60 X$ & 0.12 & 90 & 1.30 & 0.625 & --- & --- & 0.131 & 1.73 \\
\hline $1-16$ & $60 X$ & 0.12 & 90 & 1.40 & 0.625 & 0.061 & 1.64 & 0.168 & 1.97 \\
\hline $1-17$ & $60 X$ & 0.12 & 90 & 1.40 & 0.875 & --- & --- & 0.139 & 1.60 \\
\hline
\end{tabular}




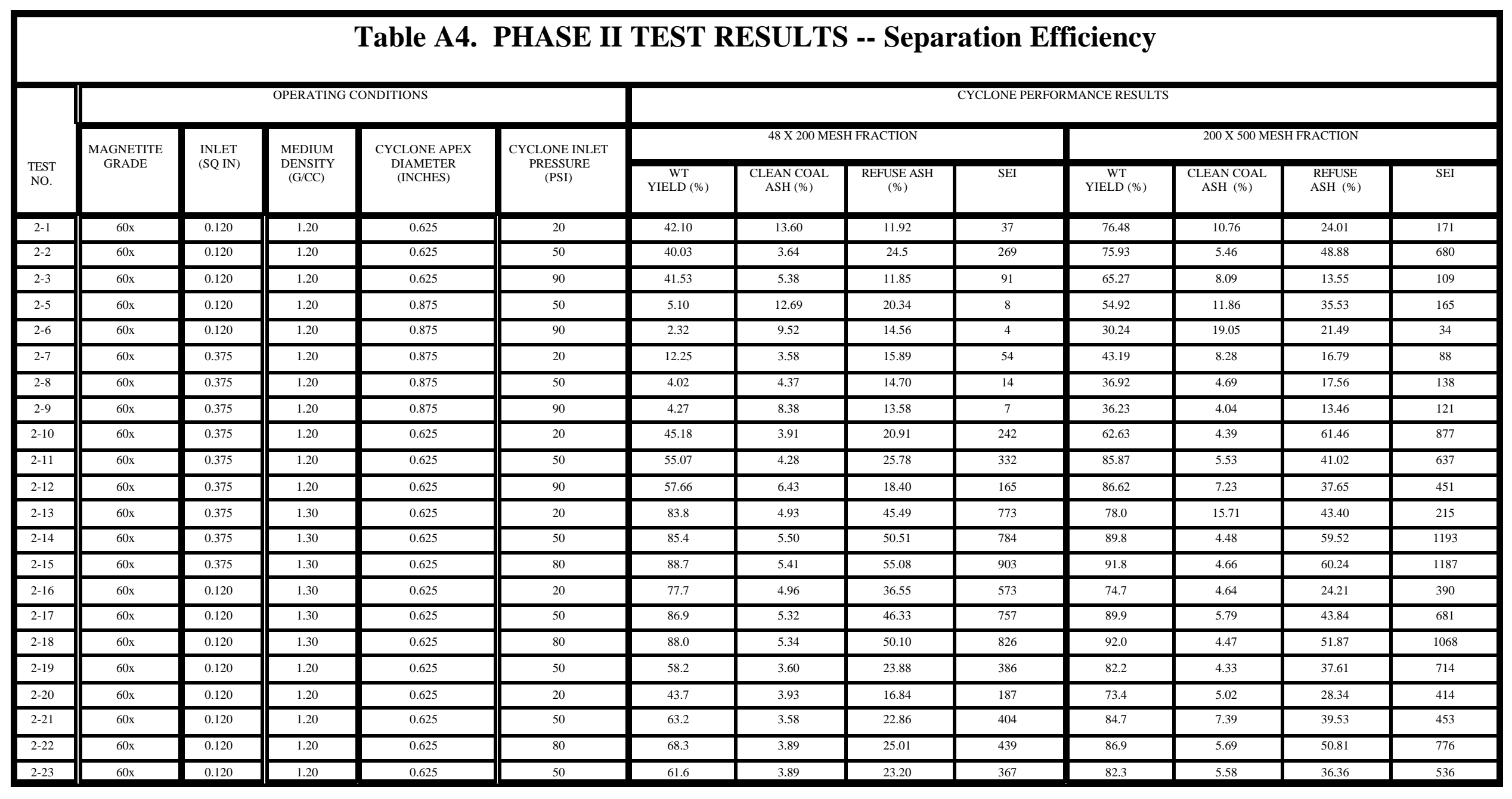




\begin{tabular}{|c|c|c|c|c|c|c|c|c|c|c|c|c|}
\hline \multirow[b]{4}{*}{$\begin{array}{c}\text { TEST } \\
\text { NO. }\end{array}$} & \multicolumn{11}{|c|}{$\begin{array}{c}\text { Table A5. PHASE II QA/QC RESULTS } \\
\text { GRADE 60x, 0.12 SQ IN INLET, 0.625" APEX, 1.20 MED DENSITY, \& 50 PSI INLET PRESSURE) }\end{array}$} & \\
\hline & \multicolumn{11}{|c|}{ CYCLONE PERFORMANCE RESULTS } & \\
\hline & \multicolumn{5}{|c|}{48 X 200 MESH FRACTION } & & \multicolumn{5}{|c|}{200 X 500 MESH FRACTION } & \multirow[b]{2}{*}{ SEI } \\
\hline & $\begin{array}{l}\text { WEIGHT } \\
\text { YIELD } \\
(\%)\end{array}$ & $\begin{array}{l}\text { CLEAN } \\
\text { COAL } \\
\text { ASH } \\
(\%)\end{array}$ & $\begin{array}{l}\text { REFUSE } \\
\text { ASH } \\
(\%)\end{array}$ & Ep & SG50 & SEI & $\begin{array}{l}\text { WEIGHT } \\
\text { YIELD } \\
(\%)\end{array}$ & $\begin{array}{l}\text { CLEAN } \\
\text { COAL } \\
\text { ASH } \\
(\%)\end{array}$ & $\begin{array}{c}\text { REFUSE } \\
\text { ASH } \\
(\%)\end{array}$ & Ep & SG50 & \\
\hline $2-2$ & 40.0 & 3.64 & 24.50 & 0.064 & 1.33 & 269 & 75.93 & 5.46 & 48.88 & NA & 1.64 & 680 \\
\hline $2-19$ & 58.2 & 3.60 & 23.88 & 0.050 & 1.37 & 386 & 82.2 & 4.33 & 37.61 & 0.166 & 1.61 & 714 \\
\hline $2-21$ & 63.2 & 3.58 & 22.86 & 0.042 & 1.36 & 404 & 84.7 & 7.39 & 39.53 & 0.214 & 1.60 & 453 \\
\hline $2-23$ & 61.6 & 3.89 & 23.20 & 0.038 & 1.36 & 367 & 82.3 & 5.58 & 36.36 & 0.162 & 1.60 & 536 \\
\hline AVG & 55.8 & 3.68 & 23.61 & 0.049 & 1.36 & 356 & 81.3 & 5.69 & 40.60 & 0.181 & 1.61 & 596 \\
\hline ST DEV & 10.7 & 0.14 & 0.73 & 0.011 & 0.02 & 60 & 3.8 & 1.27 & 5.68 & 0.029 & 0.02 & 123 \\
\hline
\end{tabular}




\begin{tabular}{|c|c|c|c|c|c|c|c|c|c|}
\hline & \multicolumn{9}{|c|}{ Table A6. PHASE II PARTITION CURVE RESULTS } \\
\hline \multirow{3}{*}{$\begin{array}{l}\text { TEST } \\
\text { NO. }\end{array}$} & \multicolumn{5}{|c|}{ OPERATING CONDITIONS } & \multicolumn{4}{|c|}{ CYCLONE PERFORMANCE } \\
\hline & \multirow{2}{*}{$\begin{array}{c}\text { MAGNETITE } \\
\text { GRADE }\end{array}$} & \multirow{2}{*}{$\begin{array}{c}\text { INLET } \\
\text { (SQ IN) }\end{array}$} & \multirow{2}{*}{$\begin{array}{c}\text { FEED } \\
\text { PRESSURE } \\
\text { (PSI) }\end{array}$} & \multirow{2}{*}{$\begin{array}{c}\text { MEDIUM } \\
\text { DENSITY } \\
(\mathrm{G} / \mathrm{CC})\end{array}$} & \multirow{2}{*}{$\begin{array}{c}\text { APEX } \\
\text { ORIFICE } \\
\text { (INCHES) }\end{array}$} & \multicolumn{2}{|c|}{$\begin{array}{c}48 \times 200 \\
\text { MESH }\end{array}$} & \multicolumn{2}{|c|}{$\begin{array}{c}200 \times 500 \\
\text { MESH }\end{array}$} \\
\hline & & & & & & Ep & SG50 & Ep & $\begin{array}{c}\text { SG5 } \\
0\end{array}$ \\
\hline $2-2$ & $60 X$ & 0.120 & 50 & 1.20 & 0.625 & 0.064 & 1.33 & NA & 1.64 \\
\hline $2-8$ & $60 X$ & 0.375 & 50 & 1.20 & 0.875 & NA & NA & NA & 1.41 \\
\hline $2-10$ & $60 X$ & 0.375 & 20 & 1.20 & 0.625 & 0.061 & 1.33 & 0.132 & 1.50 \\
\hline $2-11$ & $60 X$ & 0.375 & 50 & 1.20 & 0.625 & 0.047 & 1.34 & 0.136 & 1.64 \\
\hline $2-12$ & $60 X$ & 0.375 & 90 & 1.20 & 0.625 & 0.051 & 1.34 & 0.142 & 1.64 \\
\hline $2-13$ & $60 x$ & 0.375 & 20 & 1.30 & 0.625 & 0.034 & 1.47 & NA & 1.53 \\
\hline $2-14$ & $60 X$ & 0.375 & 50 & 1.30 & 0.625 & 0.043 & 1.50 & 0.161 & 1.64 \\
\hline $2-15$ & $60 X$ & 0.375 & 80 & 1.30 & 0.625 & 0.051 & 1.53 & 0.118 & 1.69 \\
\hline $2-17$ & $60 X$ & 0.120 & 50 & 1.30 & 0.625 & 0.044 & 1.50 & NA & 1.70 \\
\hline $2-18$ & $60 X$ & 0.120 & 80 & 1.30 & 0.625 & 0.049 & 1.52 & 0.135 & 1.74 \\
\hline $2-19$ & $60 X$ & 0.120 & 50 & 1.20 & 0.625 & 0.050 & 1.37 & 0.166 & 1.61 \\
\hline $2-21$ & $60 X$ & 0.120 & 50 & 1.20 & 0.625 & 0.042 & 1.36 & 0.214 & 1.60 \\
\hline $2-23$ & $60 X$ & 0.120 & 50 & 1.20 & 0.625 & 0.038 & 1.36 & 0.162 & 1.60 \\
\hline
\end{tabular}

